ARTICLE

\title{
Self-assembly of an anion receptor with metal-dependent kinase inhibition and potent in vitro anti-cancer properties
}

Simon J. Allison (10 ${ }^{1 凶}$, Jaroslaw Bryk ${ }^{1}$, Christopher J. Clemett (10 ${ }^{1}$, Robert A. Faulkner (1) ${ }^{1}$, Michael Ginger ${ }^{1}$, Hollie B. S. Griffiths ${ }^{1}$, Jane Harmer (1) 1, P. Jane Owen-Lynch (1) 1, Emma Pinder (D) ${ }^{1}$, Heiko Wurdak ${ }^{2}$, Roger M. Phillips ${ }^{1 凶} \&$ Craig R. Rice (i) ${ }^{1 凶}$

One topical area of supramolecular chemistry is the binding of anionic species but despite the importance of anions in diverse cellular processes and for cancer development, anion receptors or 'binders' have received little attention as potential anti-cancer therapeutics. Here we report self-assembling trimetallic cryptands (e.g. $\left[\mathbf{L}_{2}(\mathrm{Metal})_{3}\right]^{6+}$ where Metal $=\mathrm{Cu}^{2+}$, $\mathrm{Zn}^{2+}$ or $\mathrm{Mn}^{2+}$ ) which can encapsulate a range of anions and which show metal-dependent differences in chemical and biological reactivities. In cell studies, both $\left[\mathbf{L}_{2} \mathrm{Cu}_{3}\right]^{6+}$ and $\left[\mathbf{L}_{2} \mathrm{Zn}_{3}\right]^{6+}$ complexes are highly toxic to a range of human cancer cell lines and they show significant metal-dependent selective activity towards cancer cells compared to healthy, non-cancerous cells (by up to 2000-fold). The addition of different anions to the complexes (e.g. $\mathrm{PO}_{4}{ }^{3-}, \mathrm{SO}_{4}{ }^{2-}$ or $\mathrm{PhOPO}_{3}{ }^{2-}$ ) further alters activity and selectivity allowing the activity to be modulated via a self-assembly process. The activity is attributed to the ability to either bind or hydrolyse phosphate esters and mechanistic studies show differential and selective inhibition of multiple kinases by both $\left[\mathbf{L}_{2} \mathrm{Cu}_{3}\right]^{6+}$ and $\left[\mathbf{L}_{2} \mathrm{Zn}_{3}\right]^{6+}$ complexes but via different mechanisms.

\footnotetext{
${ }^{1}$ School of Applied Sciences, University of Huddersfield Queensgate, Huddersfield, UK. ${ }^{2}$ School of Medicine, University of Leeds, Leeds, UK.

凶email: s.allison@hud.ac.uk; r.m.phillips@hud.ac.uk; c.r.rice@hud.ac.uk
} 
C ontemporary medicines range from the relatively simple such as lithium salts for the treatment of bipolar disorder, to large and complex organic structures for cancer therapy, which can contain hundreds of atoms and dozens of chiral centres $^{1}$. However, despite their large diversity they all share a commonality; viz all are discrete molecular species that have to be chemically prepared often via an iterative synthetic procedure. A different approach to this is the use of self-assembly, which is a process where a disordered system of pre-existing compounds forms an organised structure as a consequence of specific preprogrammed interactions among the components themselves ${ }^{2-9}$. Self-assembly offers easy and rapid access to a library of molecularly complex architectures and novel compounds all of which may have differing biological activity without the need for a chemist to conventionally synthesise the differing molecules.

To date artificial self-assembling systems have received relatively little attention for potential therapeutic applications despite self-assembly becoming a mature area of scientific study ${ }^{10-14}$. However, there are some notable advances in this area, for example Hannon and co-workers have shown that a dinuclear triple helicate (e.g. $\left[\mathrm{L}_{3} \mathrm{Fe}_{2}\right]^{4+}$ ) interacts strongly with duplex DNA, and displays both anti-cancer and anti-bacterial properties $^{15-17}$. Scott and co-workers have demonstrated that Fe(II)-containing "head-to-head-to-tail" helicates show toxic and selective in vitro cytotoxic activity against a range of cancer cell lines with $\mathrm{IC}_{50}$ values lower than cis-platin ${ }^{18}$. Ruthenium containing transition metal helicates and mesocates have also been shown to have interesting biological properties with some showing higher cytotoxicity towards cancer cells that lack p53 ${ }^{19}$. Metallacycles and metallacages have also been shown to possess useful properties with HHan's $\left[\mathrm{Pd}_{2} \mathrm{~L}_{4}\right]^{4+}$ cages showing cytotoxicity towards an array of different human cancer cell lines ${ }^{20}$. Unsurprisingly, many of these active assemblies contain $\mathrm{Pt}^{2+}$ as its cytotoxic effects are well known and these have been shown to have activity towards a number of cancer cell lines, with some assemblies used to encapsulate and target cis-platin delivery ${ }^{21}$.

The binding of anionic species, for example by synthetic scaffolds containing hydrogen-bond donor units, is a topical area of supramolecular chemistry ${ }^{22-27}$. Due to the importance of different anions in diverse biological processes it would seem highly likely that anion binders would have interesting biological effects and potentially could have valuable therapeutic properties where anion-dependent processes are perturbed ${ }^{28}$. Indeed, recent results have shown that synthetic chloride transporters can compensate for insufficient chloride fluxes in cystic fibrosis however, any potential anti-cancer properties of anion receptors have yet to be explored ${ }^{29,30}$. We have previously demonstrated that the tripodal ligand $\mathbf{L}$, which contains three bidentate $\mathrm{N}$-donor units separated by a tris (2-aminoethyl) amine spacer, forms a cryptand with $\mathrm{Cu}^{2+}$ (e.g. $\left[\mathrm{L}_{2} \mathrm{Cu}_{3}\right]^{6+}$ ). These assembles can bind a large variety of anions of different geometries and the complex can efficiently remove phosphate anions from aqueous media, reducing levels from 1000 to $<0.1 \mathrm{ppm}$, even in the presence of competitive species ${ }^{31}$.

In this work we demonstrate that the tripodal ligand $\mathbf{L}$ also selfassembles with both $\mathrm{Zn}^{2+}$ and $\mathrm{Mn}^{2+}$ ions to form a trinuclear species (e.g. $\left[\mathrm{L}_{2} \mathrm{Zn}_{3}\right]^{6+}$ ) and in these anions are encapsulated both in the solid-state and aqueous systems (e.g. $\left[\mathrm{L}_{2} \mathrm{M}_{3}\left(\mathrm{PO}_{4}\right)\right]^{3+}$ and $\left[\mathrm{L}_{2} \mathrm{M}_{3}\left(\mathrm{SO}_{4}\right)\right]^{4+}$ where $\mathrm{M}=\mathrm{Zn}^{2+}$ or $\left.\mathrm{Mn}^{2+}\right)$. Interestingly, these metal assemblies $\left(\mathrm{M}=\mathrm{Zn}^{2+}, \mathrm{Mn}^{2+}\right.$ or $\left.\mathrm{Cu}^{2+}\right)$ show different chemical reactivities towards a phenyl phosphate dianion $\left(\mathrm{PhOPO}_{3}{ }^{2-}\right)$ with the copper-containing species incorporating the anion in the assembly (e.g. $\left.\left[\mathbf{L}_{2} \mathrm{Cu}_{3}\left(\mathrm{O}_{3} \mathrm{POPh}\right)\right]^{4+}\right)$ whereas the $\mathrm{Mn}^{2+}$ and $\mathrm{Zn}^{2+}$ complexes hydrolyse the anion to phosphate at different rates (e.g. $\left[\mathrm{L}_{2} \mathrm{M}_{3}\left(\mathrm{PO}_{4}\right)\right]^{3+}$ where $\mathrm{M}=\mathrm{Zn}^{2+}$ or $\mathrm{Mn}^{2+}$ ) indicating intrinsic phosphatase activity of these complexes (Fig. 1). In cell studies, both $\left[\mathbf{L}_{2} \mathrm{Cu}_{3}\right]^{6+}$ and $\left[\mathbf{L}_{2} \mathrm{Zn}_{3}\right]^{6+}$ complexes are highly toxic to a range of human cancer cell lines as well as a glioblastoma cancer stem cell model ${ }^{32,33}$. As well as potency, both complexes show high selective activity towards cancer cells compared to healthy, non-cancerous cells (by up to 2000-fold;

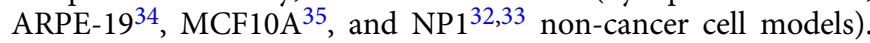
Encapsulation of either a phosphate or sulfate anion further modulates potency and selectivity. In contrast to $\mathrm{Zn}^{2+}$ and $\mathrm{Cu}^{2+}$ complexes, $\left[\mathrm{L}_{2} \mathrm{Mn}_{3}\right]^{6+}$ showed only modest selective activity which was comparable to that of clinically used platinate anticancer agents. Mechanism of action studies show that $\left[\mathbf{L}_{2} Z_{3}\right]^{6+}$ has selective phosphatase activity towards phospho-serine, phospho-tyrosine and phospho-threonine amino acids resulting in the selective inhibition of multiple kinases, cancer cell ATP depletion, autophagy and cancer cell toxicity.

\section{Results}

Synthesis and characterisation. Reaction of 1.5 equivalents of $\mathbf{L}$ with either $\mathrm{Zn}\left(\mathrm{ClO}_{4}\right)_{2}$ or $\mathrm{Mn}\left(\mathrm{ClO}_{4}\right)_{2}$ results in a mononuclear complex (e.g. $[\mathbf{L M}]^{2+}$ ) as demonstrated by X-ray crystallography and ESI-MS. In the solid-state the zinc complex contains a 6coordinate $\mathrm{Zn}^{2+}$ cation coordinated by six nitrogen atoms from three pyridyl-thiazole bidentate units from the same ligand. In the $\mathrm{Mn}^{2+}$ analogue the metal ion is again 6-coordinate, but this arises from coordination by four $\mathrm{N}$-donor atoms from two bidentate pyridyl-thiazole units and two water $\mathrm{O}$-donor atoms (Fig. 2a, b). Both complexes differ from the $\mathrm{Cu}^{2+}$ derivative which can form the trimetallic capsule (e.g. $\left[\mathbf{L}_{2} \mathrm{Cu}_{3}\right]^{6+}$ ) even in the presence of weakly interacting anions. The difference is attributed to the ability of $\mathrm{Cu}^{2+}$ to form 4-coordinate complexes (at least with pyridyl-thiazole donors) whereas both $\mathrm{Zn}^{2+}$ and $\mathrm{Mn}^{2+}$ prefer higher-coordinate geometry and without a strongly coordinating anion present a simple mononuclear species is formed. The coordination of water in the $\mathrm{Mn}^{2+}$ complex (e.g. $\left[\mathrm{LMn}\left(\mathrm{H}_{2} \mathrm{O}\right)_{2}\right]^{2+}$ ) is a consequence of the oxophillic nature of this hard cation and this behaviour is mirrored in all the structures with this metal. The formation of these species is also observed in the gas phase with ESI-MS studies showing that only ions corresponding to the mononuclear species are present.

Reaction of $\mathbf{L}$ with either $\mathrm{Mn}^{2+}$ or $\mathrm{Zn}^{2+}$ with $\left(\mathrm{Bu}_{4} \mathrm{~N}\right) \mathrm{HSO}_{4}$ (in the correct stoichiometric proportions) results in the formation of the capsule in which sulfate anions are encapsulated (e.g. $\left[\mathrm{L}_{2} \mathrm{M}_{3}\left(\mathrm{SO}_{4}\right)\right]^{4+}$ ) (Fig. $\left.2 \mathrm{c}-\mathrm{f}\right)$. In the solid state the $\mathrm{Zn}^{2+}$ is isostructural to the $\mathrm{Cu}^{2+}$ derivative with a trinuclear $\left[\mathrm{L}_{2} \mathrm{Zn}_{3}\right]^{6+}$ assembly and within it is an encapsulated sulfate anion (e.g. $\left.\left[\mathrm{L}_{2} \mathrm{Zn}_{3}\left(\mathrm{SO}_{4}\right)\right]^{4+}\right)$. Each of the three $\mathrm{Zn}^{2+}$ atoms are 5-coordinate arising from four $\mathrm{N}$-donor atoms from two bidentate pyridylthiazole units and one oxygen donor from the sulfate anion. The sulfate is held within the capsule by three coordination bonds to $\mathrm{Zn}^{2+}$ supplemented by three $-\mathrm{NH}$... O hydrogen bonding interactions. The remaining uncoordinated oxygen atom forms hydrogen bonds to three -NH donor units within the "upper rim" of the cavity. The $\mathrm{Mn}^{2+}$ forms a very similar type of assembly but each of the $\mathrm{Mn}^{2+}$ metal ions are 6-coordinate, which for one of the metal ions arises from four $\mathrm{N}$-donor atoms from two bidentate pyridyl-thiazole units and two oxygen donors from the sulfate anion. The remaining two ions are also 6-coordinate and are coordinated by two bidentate $N$-donor ligands but are coordinated by one oxygen atom from the sulfate anion and one water molecule (e.g. $\left.\left[\mathbf{L}_{2} \mathrm{Mn}_{3}\left(\mathrm{H}_{2} \mathrm{O}\right)_{2}\left(\mathrm{SO}_{4}\right)\right]^{4+}\right)$. This demonstrates that whilst with weakly interacting anions (e.g. halides, $\mathrm{ClO}_{4}{ }^{-}$, and $\mathrm{BF}_{4}^{-}$) both $\mathrm{Zn}^{2+}$ and $\mathrm{Mn}^{2+}$ form mononuclear complexes, with tetrahedral oxoanions these template the formation of the trimetallic capsule.

Ions in the ESI-MS at $\mathrm{m} / z 1844$ and 1812 corresponding to $\left\{\left[\mathrm{L}_{2} \mathrm{Zn}_{3}\left(\mathrm{SO}_{4}\right)\left(\mathrm{ClO}_{4}\right)_{3}\right\}^{+}\right.$and $\left\{\left[\mathrm{L}_{2} \mathrm{Mn}_{3}\left(\mathrm{SO}_{4}\right)\left(\mathrm{ClO}_{4}\right)_{3}\right\}^{+}\right.$coupled 


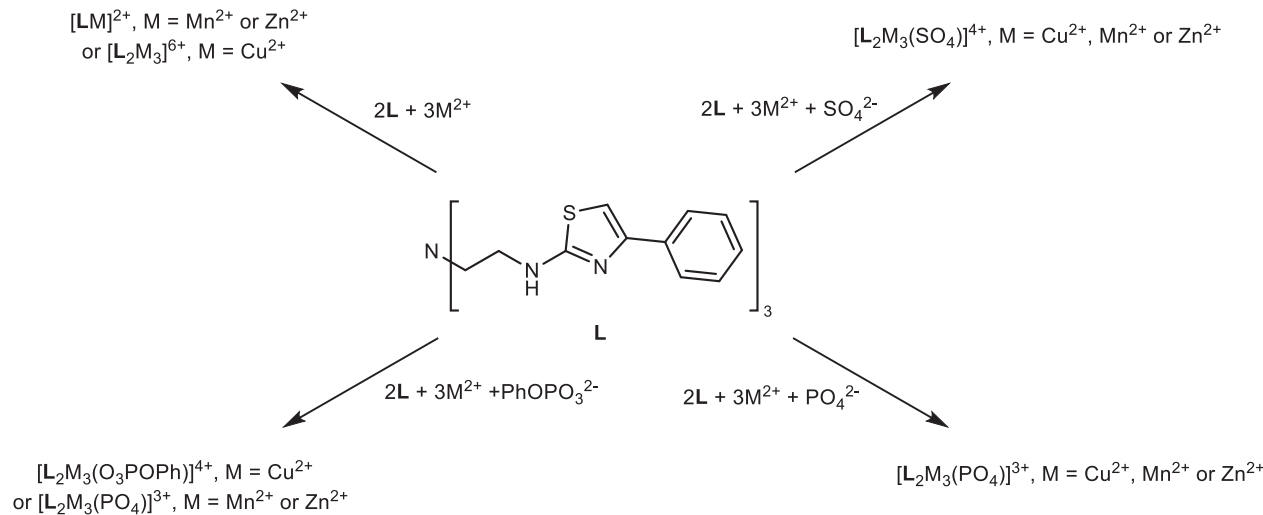

Fig. 1 Differing complexes formed with ligand $\mathbf{L}$, transition metal ions and different anions. Trimetallic assemblies are formed between $\mathrm{Cu}^{2+}$ and $\mathrm{L}$ whereas mononuclear species result upon reaction of either $\mathrm{Zn}^{2+}$ or $\mathrm{Mn}^{2+}$. Trinuclear assemblies can be formed with the latter two cations by templation by $\mathrm{SO}_{4}{ }^{2-}$ or $\mathrm{PO}_{4}{ }^{3-}$. $\mathrm{PhOPO}_{3}{ }^{2-}$ is encapsulated by the copper complex but is hydrolysed to $\mathrm{PO}_{4}{ }^{3-}$ when either the $\mathrm{Zn}^{2+}$ or $\mathrm{Mn}^{2+}$ are used. Reaction of the ligand $\mathbf{L}$ with $\mathrm{Cu}^{2+}, \mathrm{Zn}^{2+}$ and $\mathrm{Mn}^{2+}$ and various anions.

with doubly charged ions indicate that these species are also observed in the gas phase.

Addition of disodium phenylphosphate to a solution of $\left[\mathrm{L}_{2} \mathrm{Cu}_{3}\right]^{6+}$ in $\mathrm{MeCN} / \mathrm{H}_{2} \mathrm{O}$ results in a colour change from light blue to green. Crystals were then deposited after several days and analysis by X-ray crystallography shows that the trimetallic capsule is still formed but held inside the host is a $\mathrm{PhOPO}_{3}{ }^{2-}$ anion. In a very similar fashion to the other oxoanions, $\mathrm{PhOPO}_{3}{ }^{2-}$ is coordinated to the three $\mathrm{Cu}^{2+}$ metal ions supplemented by a series of - $\mathrm{NH}$-...anion interactions. However, due to the phenyl substituent the ligands adopt a slightly different conformation allowing the phenyl unit to occupy a cleft formed by two pyridyl-thiazole units (Fig. 3a, b).

Reaction of two equivalents of $\mathbf{L}$, three equivalents of either $\mathrm{M}$ $\left(\mathrm{ClO}_{4}\right)_{2}$ (where $\mathrm{M}=\mathrm{Zn}^{2+}$ or $\mathrm{Mn}^{2+}$ ) and $\mathrm{PhOPO}_{3} \mathrm{Na}_{2}$ results in a very different species. In the solid-state both structures contain a central $\mathrm{PO}_{4}{ }^{3-}$ anion held within the molecule by a series of interactions between the metal ions and amine hydrogen atoms (Fig. 3c-f). The $\left[\mathbf{L}_{2} \mathrm{Mn}_{3}\left(\mathrm{PO}_{4}\right)\right]^{3+}$ complex is similar to the sulfate analogue and the three 6-coordinate $\mathrm{Mn}^{2+}$ metal ions are coordinated by two bidentate $\mathrm{N}$-donor ligand domains but one metal ion is coordinated by two oxygen atoms from the anion and the remaining two metal ions are coordinated by one anion oxygen atom and a water molecule. The $\left[\mathbf{L}_{2} \mathrm{Zn}_{3}\left(\mathrm{PO}_{4}\right)\right]^{3+}$ is slightly different from the sulfate analogue and one metal ion is 6coordinate arising from coordination of two bidentate $\mathrm{N}$-donor ligand units and two oxygen atoms of the anion. The remaining two metal ions are only 5 -coordinate as only one oxygen atom from the anion interacts with the metal.

This metal-dependent reactivity is also observed in the ESI-MS. Reaction of $\left[\mathbf{L}_{2} \mathrm{Cu}_{3}\right]\left(\mathrm{ClO}_{4}\right)_{6}$ with $\mathrm{PhOPO}_{3} \mathrm{Na}_{2}$ in water and $\mathrm{MeCN}$ gives ions at $\mathrm{m} / \mathrm{z} 1914,1024,788$ and 463 corresponding to $\left\{\left[\mathbf{L}_{2} \mathrm{Cu}_{3}\left(\mathrm{PhOPO}_{3}\right)\right]\left(\mathrm{ClO}_{4}\right)_{3}\right\}^{+}, \quad\left\{\left[\mathbf{L C u}_{2}\left(\mathrm{PhOPO}_{3}\right)\right]\left(\mathrm{ClO}_{4}\right)\right\}^{+}, \quad\{[\mathbf{L C u}]$ $\left.\left(\mathrm{ClO}_{4}\right)\right\}^{+}$and $\left\{\left[\mathrm{LCu}_{2}\left(\mathrm{PhOPO}_{3}\right)\right]\right\}^{2+}$. Heating this sample at $80^{\circ} \mathrm{C}$ shows no change in the ESI-MS spectrum indicating that the phenylphosphate dianion remains intact. A similar reaction of $\mathrm{PhOPO}_{3} \mathrm{Na}_{2}$ with $\mathrm{Zn}\left(\mathrm{ClO}_{4}\right)_{2}$ and $\mathbf{L}$ gave an ESI-MS with ions at $\mathrm{m} / \mathrm{z}$ 1920 and 910 corresponding to $\left\{\left[\mathbf{L}_{2} \mathrm{Zn}_{3}\left(\mathrm{PhOPO}_{3}\right)\right]\left(\mathrm{ClO}_{4}\right)_{3}\right\}^{+}$and $\left\{\left[\mathbf{L}_{2} \mathrm{Zn}_{3}\left(\mathrm{PhOPO}_{3}\right)\right]\left(\mathrm{ClO}_{4}\right)_{2}\right\}^{2+}$ respectively. Lower molecular weight ions at $\mathrm{m} / \mathrm{z} 1029,791$ and 464 corresponding to $\left\{\left[\mathrm{LZn}_{2}\left(\mathrm{PhOPO}_{3}\right)\right]\right.$ $\left.\left(\mathrm{ClO}_{4}\right)\right\}^{+},\left\{[\mathbf{L Z n}]\left(\mathrm{ClO}_{4}\right)\right\}^{+}$and $\left\{\left[\mathbf{L Z n}_{2}\left(\mathrm{PhOPO}_{3}\right)\right]\right\}^{2+}$ were also observed. However, heating this sample at $80^{\circ} \mathrm{C}$ results in a dramatic change in the ESI-MS with the spectrum now much simplified with ions at $\mathrm{m} / \mathrm{z} 1743$ and 822 corresponding to $\left\{\left[\mathbf{L}_{2} \mathrm{Zn}_{3}\left(\mathrm{PO}_{4}\right)\right]\left(\mathrm{ClO}_{4}\right)_{2}\right\}^{+}$and $\left\{\left[\mathbf{L}_{2} \mathrm{Zn}_{3}\left(\mathrm{PO}_{4}\right)\right]\left(\mathrm{ClO}_{4}\right)\right\}^{2+}$. This demonstrates that initially the $\mathrm{Zn}^{2+}$ containing complex reacts with phenyl phosphate dianion and in a similar fashion to the $\mathrm{Cu}^{2+}$ analogue and forms the trinuclear complex incorporating this anion (e.g. $\left.\left[\mathbf{L}_{2} \mathrm{Zn}_{3}\left(\mathrm{PhOPO}_{3}\right)\right]^{4+}\right)$. However, after either a few days at room temperature or heating at $80^{\circ} \mathrm{C}$ for $1 \mathrm{~h}$ the anion is hydrolysed and phosphate is encapsulated within the cryptand (see Supplementary Information). This hydrolysis is also confirmed by ${ }^{1} \mathrm{H}$ NMR as reaction of two equivalents of $\mathbf{L}$, three equivalents of $\mathrm{Zn}\left(\mathrm{ClO}_{4}\right)_{2}$ and $\mathrm{PhOPO}_{3} \mathrm{Na}_{2}$ initially gives a broad complex spectrum but after $1 \mathrm{~h}$ at $80^{\circ} \mathrm{C}$ gave a spectrum that contains signals corresponding to $\left[\mathrm{L}_{2} \mathrm{Zn}_{3}\left(\mathrm{PO}_{4}\right)\right]^{3+}$ accompanied with signals corresponding to the phenol hydrolysis product. Reaction with $\mathrm{Mn}\left(\mathrm{ClO}_{4}\right)_{2}$ is similar to the $\mathrm{Zn}^{2+}$ analogue with ions in the ESI-MS corresponding to binding of phenyl phosphate observed initially (e.g. $\left.\left\{\left[\mathbf{L M n}_{2}\left(\mathrm{PhOPO}_{3}\right)\right]\left(\mathrm{ClO}_{4}\right)\right\}^{+}\right)$but ions corresponding to hydrolysis (e.g. $\left\{\left[\mathbf{L}_{2} \mathrm{Mn}_{3}\left(\mathrm{PO}_{4}\right)\right]\left(\mathrm{ClO}_{4}\right)_{2}\right\}^{+}$and $\left.\left\{\left[\mathbf{L}_{2} \mathrm{Mn}_{3}\left(\mathrm{PO}_{4}\right)\right]\left(\mathrm{ClO}_{4}\right)\right\}^{2+}\right)$ are observed after heating for $1 \mathrm{~h}^{36}$.

The $\mathrm{Zn}^{2+}$ complex shows substrate specific differences in the rates of hydrolysis and its phosphatase activity. Analysis of the hydrolysis of phenyl phosphate dianion by the $\mathrm{Zn}^{2+}$ complex (in a 25\%:75\% mixture of DMSO and buffered $\mathrm{H}_{2} \mathrm{O}$ solution (HEPES $60 \mathrm{mmol}, p \mathrm{H} 7.5)$ ) by ${ }^{31} \mathrm{P}$ NMR shows a signal at $-1.5 \mathrm{ppm}$ corresponding to unhydrolysed $\mathrm{PhOPO}_{3}{ }^{2-}$ at $t=0$ (Fig. 4, spectra b). After $19 \mathrm{~h}$ at $37^{\circ} \mathrm{C}$ the major signal present is now observed at $8.6 \mathrm{ppm}$ which is at an identical chemical shift to $\left[\mathrm{L}_{2} \mathrm{Zn}_{3}\left(\mathrm{PO}_{4}\right)\right]^{3+}$ and after $44 \mathrm{~h}$ virtually no signal corresponding to $\mathrm{PhOPO}_{3}{ }^{2-}$ is observed (Fig. 4, spectra $\mathrm{c}$, d). In a similar experiment using 4-nitrophenyl phosphate no ${ }^{31} \mathrm{P}$ signals could be detected that corresponded to the starting material following mixing with the $\mathrm{Zn}^{2+}$ complex indicating almost immediate hydrolysis. Only $\left[\mathrm{L}_{2} \mathrm{Zn}_{3}\left(\mathrm{PO}_{4}\right)\right]^{3+}$ was observed, coupled with a rapid yellowing of the solution due to the formation of 4nitrophenolate.

Given the importance of protein phosphorylation in inter- and intra- cellular signalling and to cell function, and its common dysregulation in cancers ${ }^{37,38}$, it was next analysed whether the $\mathrm{Zn}^{2+}$ complex could dephosphorylate the phosphorylated amino acids serine, threonine and tyrosine. Indeed, the $\mathrm{Zn}^{2+}$ complex resulted in dephosphorylation of serine- $\mathrm{OPO}_{3}{ }^{2-}$ and tyrosine$\mathrm{OPO}_{3}{ }^{2-}$ at similar hydrolysis rates to $\mathrm{PhOPO}_{3}{ }^{2-}$ with substantial hydrolysis occurring over $24 \mathrm{~h}$ and completion after $48 \mathrm{~h}$ (Fig. 4, spectra $\mathrm{e}-\mathrm{h} ; \mathrm{m}-\mathrm{p}$ ). Dephosphorylation of the amino acid threonine- $\mathrm{OPO}_{3}^{2-}$ by the $\mathrm{Zn}^{2+}$ complex was much slower however and after $48 \mathrm{~h}$, threonine- $\mathrm{OPO}_{3}{ }^{2-}$ was still the major species (Fig. 4, spectra i-l). Differences in reactivity towards different substrates can be attributed to both steric and electronic effects. The difference in reactivity towards phenyl phosphate compared to the 4-nitro derivative is likely a consequence of the 
a

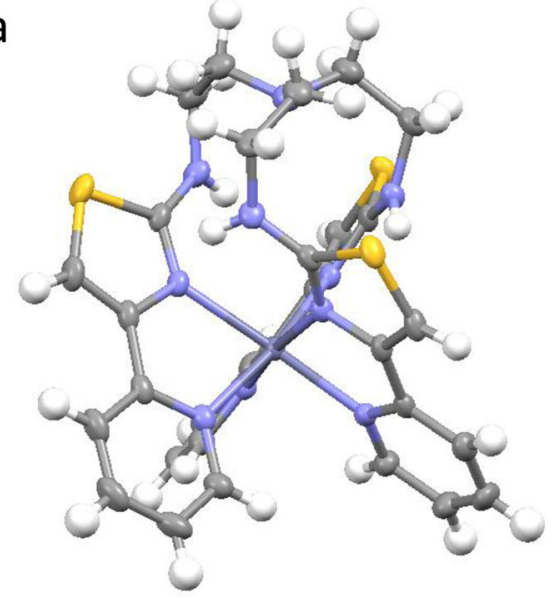

C
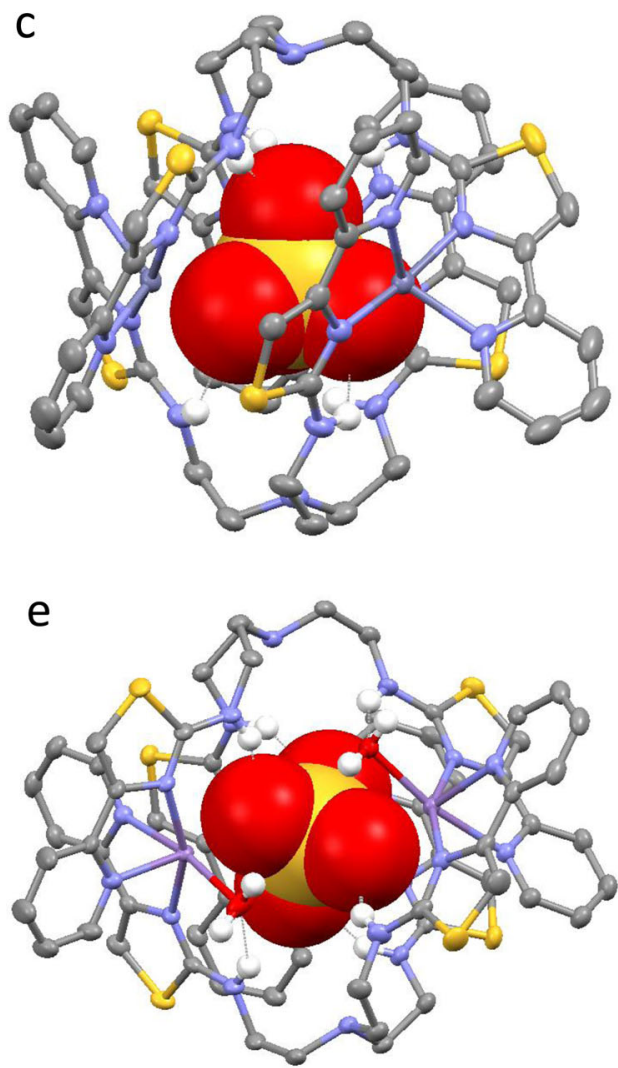

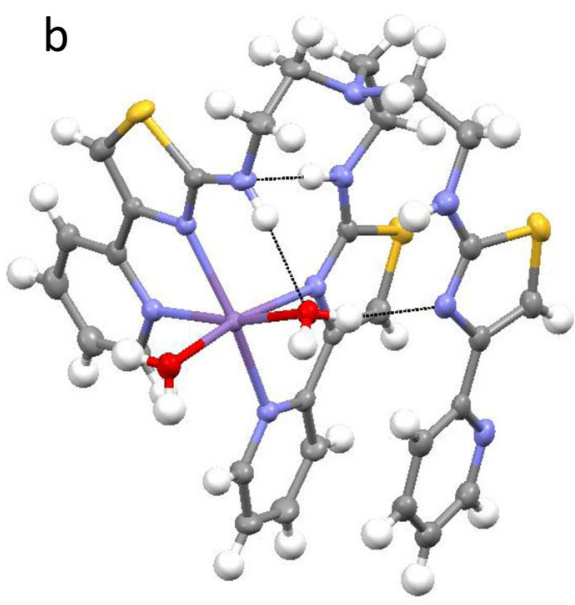

d

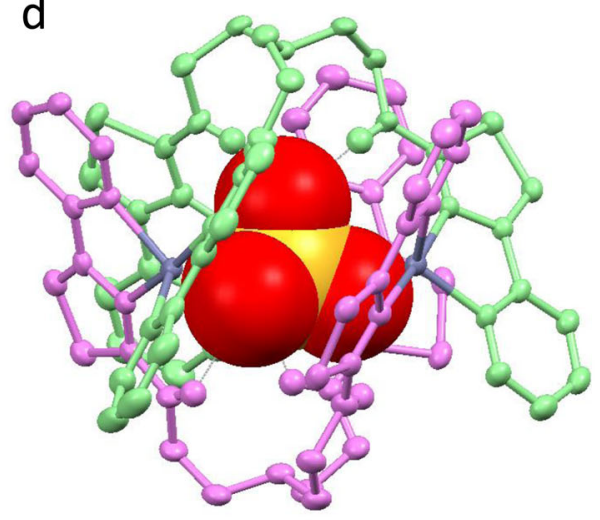

$f$

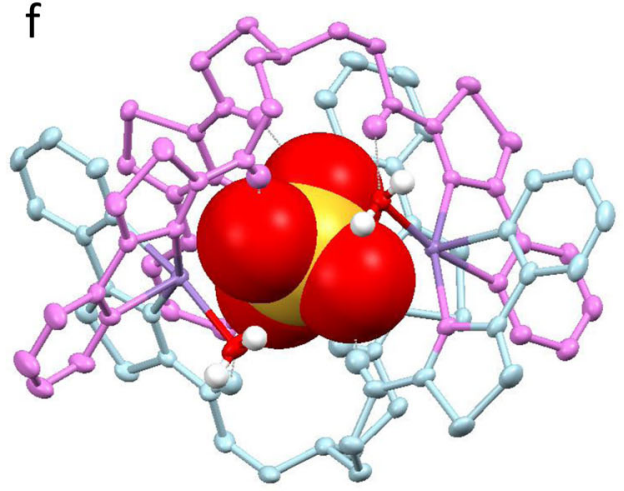

Fig. 2 Single-crystal X-ray structures of metal-containing complexes of $\mathbf{L}$. a $[\mathrm{LZn}]^{2+}$. b $\left[\mathbf{L M n}\left(\mathrm{H}_{2} \mathrm{O}\right)_{2}\right]^{2+} \cdot \mathbf{c}\left[\mathbf{L}_{2} \mathrm{Zn}_{3}\left(\mathrm{SO}_{4}\right)\right]^{4+} \cdot \mathbf{d}\left[\mathbf{L}_{2} \mathrm{Zn}_{3}\left(\mathrm{SO}_{4}\right)\right]^{4+}$. e $\left[\mathbf{L}_{2} \mathrm{Mn}_{3}\left(\mathrm{H}_{2} \mathrm{O}\right)_{2}\left(\mathrm{SO}_{4}\right)\right]^{4+}$. f $\left[\mathbf{L}_{2} \mathrm{Mn}_{3}\left(\mathrm{H}_{2} \mathrm{O}\right)_{2}\left(\mathrm{SO}_{4}\right)\right]^{4+}$. Colour code: dark blue, $\mathrm{Zn}(\mathrm{II}) ;$ purple, $\mathrm{Mn}$; red, O; blue, N; yellow, S; grey, $\mathrm{C}$ (apart from $\mathbf{2 d}$ and $\mathbf{2 f}$ where the ligand strands have been coloured for clarity).

electron-withdrawing nitro group, which will enhance the hydrolysis. Serine- $\mathrm{PO}_{3}{ }^{2-}$, tyrosine- $\mathrm{OPO}_{3}{ }^{2-}$ and threonine$\mathrm{OPO}_{3}{ }^{2-}$ all have similar electronic properties, but threonine has a methyl substituent close to the phosphorylated residue and it would seem likely this would result in unfavourable steric interactions upon binding of $\left[\mathbf{L}_{2} \mathrm{Zn}_{3}\right]^{6+}$ as the $-\mathrm{CHCH}_{3}$ unit would be housed deep in the cleft of the self-assembled species (see Fig. 3a, b). It seems probable that this interaction would reduce the ability of the cryptand to bind the anion and hence reduce the hydrolysis rate. Both serine and tyrosine are less sterically demanding (tyrosine- $\mathrm{OPO}_{3}{ }^{2-}$ is very similar to $\mathrm{PhOPO}_{3}{ }^{2-}$ and serine- $\mathrm{PO}_{3}{ }^{2-}$ has a less sterically demanding $-\mathrm{CH}_{2}{ }^{-}$unit in this position) and consequently are hydrolysed more rapidly. In all cases, in a similar fashion to that observed with phenyl phosphate (Supplementary Fig. 4.2), we presume the phosphorylated amino acids are hydrolysed to the corresponding alcohol.

The rate of substrate hydrolysis is also dependent upon the metal used in the self-assembly process. It is clear from the solidstate and ESI-MS data that $\left[\mathbf{L}_{2} \mathrm{Cu}_{3}\right]^{6+}$ does not hydrolyse phenyl phosphate but incorporates this anion within the assembly e.g. $\left[\mathbf{L}_{2} \mathrm{Cu}_{3}\left(\mathrm{PhOPO}_{3}\right)\right]^{4+}$. Comparison of the reactivity of the $\mathrm{Zn}^{2+}$ species verses the $\mathrm{Mn}^{2+}$ by monitoring the hydrolysis of 4nitrophenyl phosphate by UV-Vis spectroscopy shows after $24 \mathrm{~h}$ the $\mathrm{Mn}^{2+}$ has hydrolysed three times more phosphate, indicating that the $\mathrm{Mn}^{2+}$ is more active than the $\mathrm{Zn}^{2+}$ complex. 
a

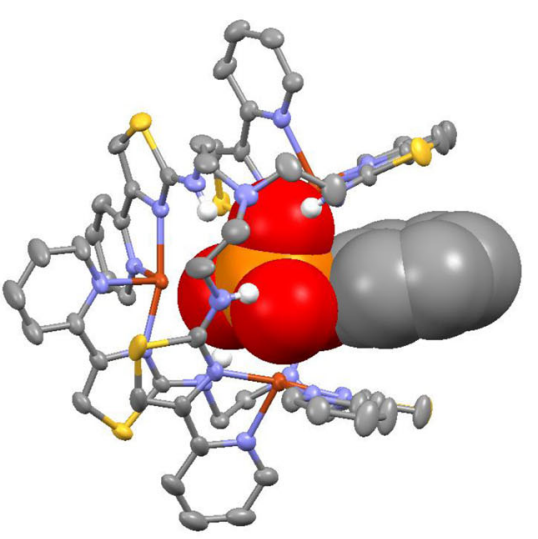

C

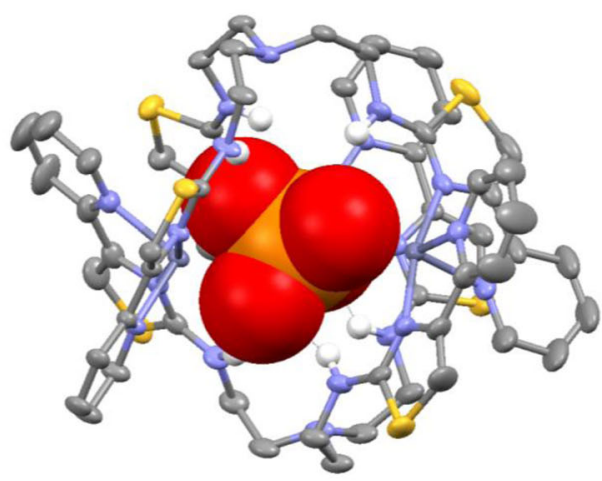

e

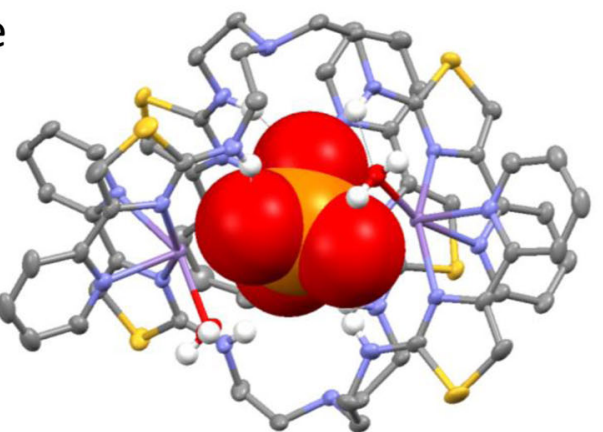

b

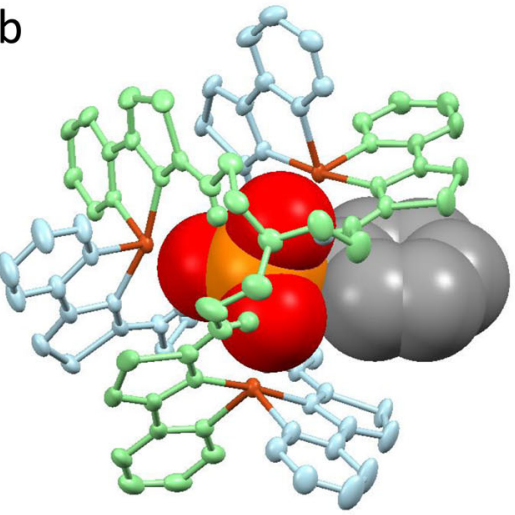

d

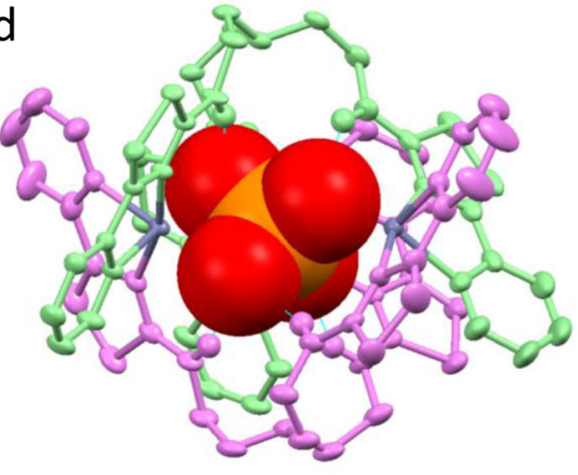

f

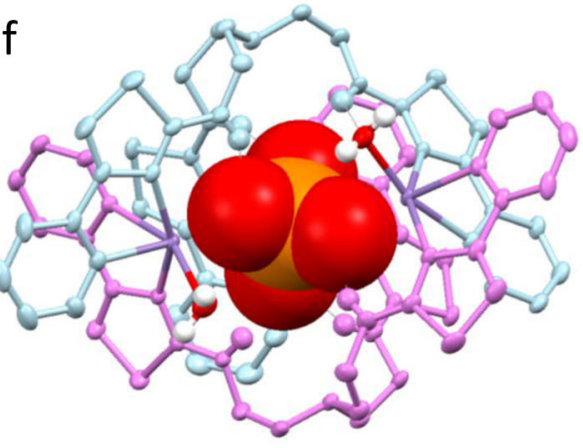

Fig. 3 X-ray structural analysis of the reaction of $\left.\left[\mathrm{L}_{\mathbf{2}} \mathbf{C u}_{\mathbf{3}}\right]^{\mathbf{6}+}, \mathrm{LL}_{\mathbf{2}} \mathbf{Z n}_{\mathbf{3}}\right]^{\mathbf{6}+}$ and $\left[\mathbf{L}_{\mathbf{2}} \mathbf{M n}_{\mathbf{3}}\right]^{\mathbf{6}+}$ with $\mathbf{P h O P O}_{\mathbf{3}} \mathbf{2}^{\mathbf{2}}$. a $\left[\mathbf{L}_{2} \mathrm{Cu}_{3}\left(\mathrm{PhOPO}_{3}\right)\right]^{4+} . \mathbf{b}\left[\mathbf{L}_{2} \mathrm{Cu}_{3}\left(\mathrm{PhOPO}_{3}\right)\right]^{4+}$. c $\left[\mathbf{L}_{2} \mathrm{Zn}_{3}\left(\mathrm{PO}_{4}\right)\right]^{3+}$. d $\left[\mathbf{L}_{2} \mathrm{Zn}_{3}\left(\mathrm{PO}_{4}\right)\right]^{3+}$. e $\left[\mathbf{L}_{2} \mathrm{Mn}_{3}\left(\mathrm{H}_{2} \mathrm{O}\right)_{2}\left(\mathrm{PO}_{4}\right)\right]^{3+}$. $\mathbf{f}\left[\mathbf{L}_{2} \mathrm{Mn}_{3}\left(\mathrm{H}_{2} \mathrm{O}\right)_{2}\left(\mathrm{PO}_{4}\right)\right]^{3+}$. Colour code: dark orange, $\mathrm{Cu}(\mathrm{II}) ;$ dark blue, $\mathrm{Zn}(\mathrm{II}) ;$ purple, $\mathrm{Mn}$; red, O; blue, $\mathrm{N}$; yellow, S; grey, C; orange, $\mathrm{P}$ (apart from 2b, $2 \mathrm{~d}$ and $2 \mathrm{f}$ where the ligand strands have been coloured for clarity).

Activity of complexes towards cells. The complexes $\left[\mathrm{L}_{2} \mathrm{Cu}_{3}\right]^{6+}$ and $\left[\mathbf{L}_{2} \mathrm{Zn}_{3}\right]^{6+}$ possess both potent and selective activity against most of the cancer cell lines tested compared to three non-cancer cell models utilised (Fig. $5 \mathrm{a}-\mathrm{d}$ ). For $\left[\mathrm{L}_{2} \mathrm{Zn}_{3}\right]^{6+}, \mathrm{IC}_{50}$ values towards the cancer cell lines ranged from $70 \pm 13 \mathrm{nM}$ against HCT116 p53 $3^{-1-}$ and up to $59.07 \pm 5.60 \mu \mathrm{M}$ against MiaPaCa2. $\mathrm{IC}_{50}$ values for both complexes were mostly sub- $\mu \mathrm{M}$ towards cancer cells (HT-29, DLD-1, HCT116 (p53 wild type and null), BxPC3, A549 and H460 cell lines) with the exceptions being the pancreatic cancer cell line PSN1 and the GBM1 glioblastoma cancer stem cell model ${ }^{32,33}$ where $\mathrm{IC}_{50}$ values were $>1 \mu \mathrm{M}$. Cancer stem cells are typically chemoresistant ${ }^{39}$, however, importantly both complexes showed preferential activity towards the GBM1 cells compared to all three non-cancer cell models which included adult human brain progenitor cells (NP1) 32,33 . The MiaPaCa2 pancreatic cancer cell line was however inherently resistant to both complexes with $\mathrm{IC}_{50}$ values $>10 \mu \mathrm{M}$ (Fig. 5a, b).
The magnitude of selectivity towards cancer cells was marked and for both $\left[\mathbf{L}_{2} \mathrm{Cu}_{3}\right]^{6+}$ and $\left[\mathbf{L}_{2} \mathrm{Zn}_{3}\right]^{6+}$ was over 10 -fold for most of the cancer cell lines compared to all three non-cancer cell models (Fig. $5 \mathrm{c}, \mathrm{d}$ ). Remarkably, for $\left[\mathbf{L}_{2} \mathrm{Zn}_{3}\right]^{6+}$ selectivity indices of over 2000 were obtained in the case of HCT116 p53-l- cancer cells compared to ARPE-19 and MCF10A non-cancer cells (Fig. 5d). For the $\left[\mathrm{L}_{2} \mathrm{Cu}_{3}\right]^{6+}$ complex, selectivity indices for many of the cancer cell lines were $>100$ with the $\left[\mathbf{L}_{2} \mathrm{Zn}_{3}\right]^{6+}$ complex resulting in even higher SIs. Interestingly, however, whereas activity of the $\left[\mathrm{L}_{2} \mathrm{Cu}_{3}\right]^{6+}$ complex was very similar against the three non-cancer cell models, the NP1 brain progenitor cells ${ }^{32,33}$ showed increased sensitivity to the $\mathrm{Zn}^{2+}$ complex.

Whilst the potency of both the $\mathrm{Zn}^{2+}$ and $\mathrm{Cu}^{2+}$ complexes (Fig. 5a, b) compares favourably with that of the clinically approved platinates (Fig. 5e), selectivity of the complexes is significantly superior under the same in vitro experimental conditions (Fig. 5c, d cf. 5f). Formation of the trinuclear species is 

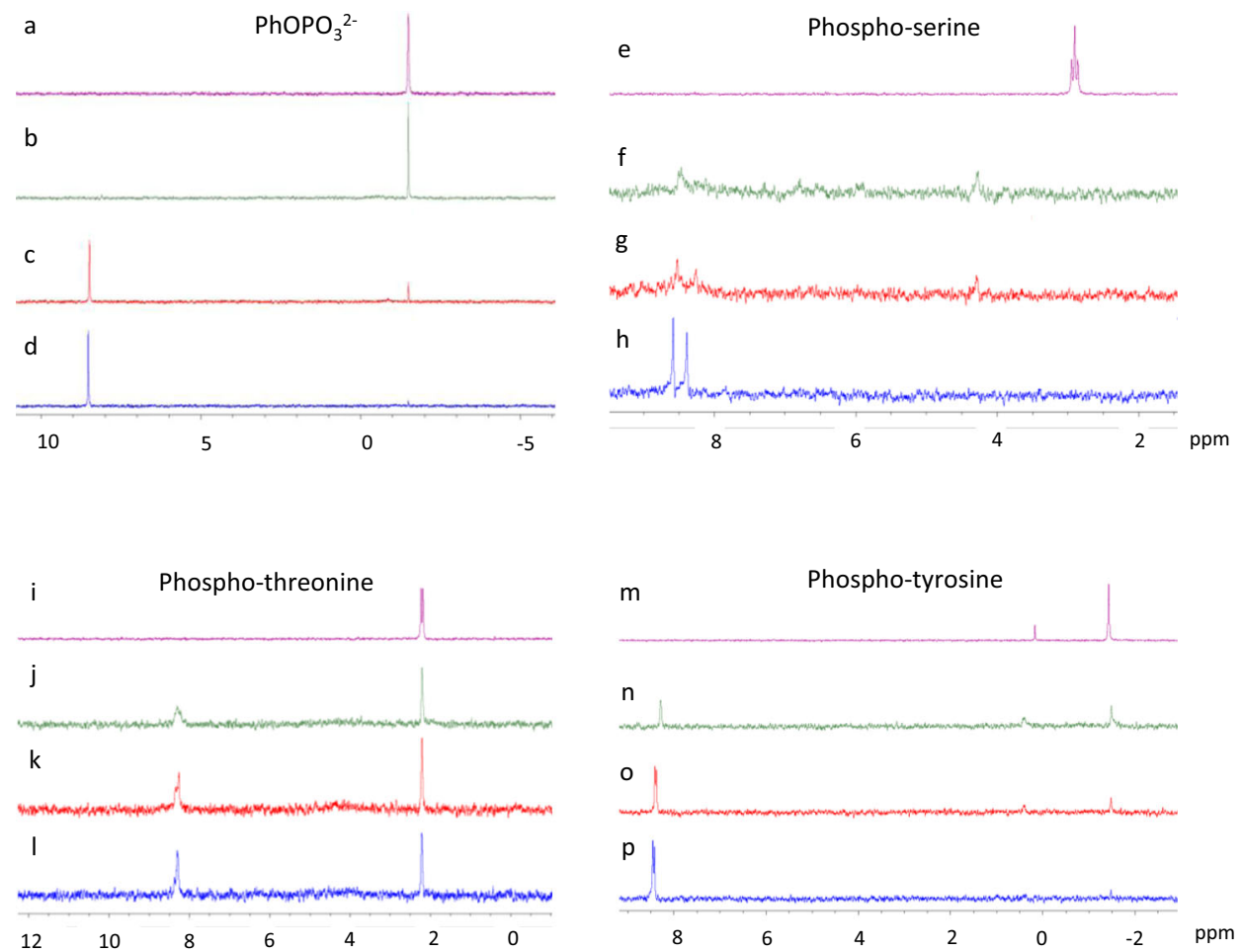

Fig. 4 Phosphatase activity of $\left[\mathbf{L}_{\mathbf{2}} \mathbf{Z n}_{\mathbf{3}}\right]^{\mathbf{6}+}$. ${ }^{31} \mathrm{P}$ NMR spectra using different substrates including $\mathrm{PhOPO}_{3}{ }^{2-}$ (spectra a-d), serine phosphate (spectra e-h), threonine phosphate (spectra $\mathbf{i}-\mathbf{I}$ ) and tyrosine phosphate (spectra $\mathbf{m}-\mathbf{p}$ ). Specific details for each ${ }^{31}$ P NMR spectra are as follows: Spectra $\mathbf{a}, \mathbf{e}, \mathbf{i}$ and $\mathbf{m}$ represent substrate alone ( $44 \mathrm{~h}$ incubated $@ 37^{\circ} \mathrm{C}$ ); Spectra $\mathbf{b}, \mathbf{f}, \mathbf{j}$ and $\mathbf{n}$ represents $\left[\mathbf{L}_{2} Z \mathrm{n}_{3}\right]^{6+}$ plus substrate $(t=0$ min); Spectra c, $\mathbf{g}, \mathbf{k}$ and $\mathbf{o}$ represents $\left[\mathbf{L}_{2} Z n_{3}\right]^{6+}$ plus substrate incubated $@ 37^{\circ} \mathrm{C}$ for $19 \mathrm{~h}$; Spectra $\mathbf{d}, \mathbf{h}, \mathbf{I}$ and $\mathbf{p}$ represents $\left[\mathbf{L}_{2} Z \mathrm{n}_{3}\right]^{6+}$ plus substrate incubated @ $37^{\circ} \mathrm{C}$ for $44 \mathrm{~h}$. The $31 \mathrm{P} \mathrm{NMR}$ of $\left[\mathbf{L}_{2} \mathrm{Zn}_{3}\left(\mathrm{PO}_{4}\right)\right]^{3+}$ gives a signal at $8.6 \mathrm{ppm}$. The doubling up of some of the ${ }^{31} \mathrm{P}$ signals in $\left[\mathbf{L}_{2} \mathrm{Zn}_{3}\left(\mathrm{PO}_{4}\right)\right]^{3+}(\mathbf{h}, \mathbf{p}$ and $\mathbf{I})$ is attributed to formation of a mixture of diastereoisomers between the racemic cryptand and the resolved chiral amino acids which will form an ion-pair $\left(\left[\mathbf{L}_{2} \mathrm{Zn}_{3}\left(\mathrm{PO}_{4}\right)\right]\left(\mathrm{RCH}\left(\mathrm{NH}_{2}\right) \mathrm{CO}\right)^{2+}\right)$ and does not occur with the achiral phenyl phosphate. ${ }^{31} \mathrm{P}$ NMR spectra of the phosphate esters are ${ }^{1} \mathrm{H}$-coupled $(\mathbf{a}, \mathbf{e}, \mathbf{i}$ and $\mathbf{m})$ and the remainder are ${ }^{1} \mathrm{H}$ decoupled.

important as solutions containing stoichiometric amounts of metal and ligand (e.g. favouring the formation of the mononuclear complex $[\mathbf{L M}]^{2+}$ ) lack selectivity in vitro as does the free ligand (Supplementary Fig. 9). In contrast, the $\mathrm{Mn}^{2+}$ complex, although a potent cytotoxin in vitro (Fig. 5e), showed only modest preferential selectivity ( 2-fold) towards cancer cells which was comparable to that of the platinates (Fig. 5f).

The encapsulation of different specific anions (e.g. $\mathrm{PO}_{4}{ }^{3-}, \mathrm{SO}_{4}{ }^{2-}$ or $\mathrm{PhOPO}_{3}{ }^{2-}$ ) into the $\left[\mathrm{L}_{2} \mathrm{Zn}_{3}\right]^{6+}$ and $\left[\mathbf{L}_{2} \mathrm{Cu}_{3}\right]^{6+}$ complexes at the point of self-assembly prior to any cell exposure impacts on both activity and selectivity. The effect is both anion and cell line dependent (Fig. 6 and see Supplementary Figs. 6-8) with the inclusion of different anions having either minimal effect or causing an increase or decrease in potency depending on the cell line. Against the PSN1 cell line for example, both $\left[\mathbf{L}_{2} \mathrm{Zn}_{3}\left(\mathrm{SO}_{4}\right)\right]^{4+}$ and $\left[\mathbf{L}_{2} \mathrm{Zn}_{3}\left(\mathrm{O}_{3} \mathrm{POPh}\right)\right]^{4+}$ are significantly more active than $\left[\mathbf{L}_{2} \mathrm{Zn}_{3}\left(\mathrm{PO}_{4}\right)\right]^{3+}$ or $\left[\mathbf{L}_{2} \mathrm{Zn}_{3}\right]^{6+}$ and this translates into improved selectivity indices using the ARPE-19 cell line as baseline (Fig. 6). A similar but smaller increase in potency was also observed against HCT116 p53 ${ }^{+/+}$(but not the p53 null variant) and $\mathrm{H} 460$ cells treated with $\left[\mathrm{L}_{2} \mathrm{Zn}_{3}\left(\mathrm{SO}_{4}\right)\right]^{4+}$ and $\left[\mathbf{L}_{2} \mathrm{Zn}_{3}\left(\mathrm{O}_{3} \mathrm{POPh}\right)\right]^{4+}$ leading to a corresponding increase in relative selectivity. In contrast, the inclusion of anions reduced the activity of $\left[\mathrm{L}_{2} \mathrm{Zn}_{3}\right]^{6+}$ against HT29, DLD-1, BxPC3 and A549 cells resulting in a corresponding reduction in relative selectivity (Fig. 6). Similar results were obtained with $\left[\mathrm{L}_{2} \mathrm{Cu}_{3}\right]^{6+}$ complexes with $\mathrm{PO}_{4}{ }^{3-}, \mathrm{SO}_{4}{ }^{2-}$ or $\mathrm{PhOPO}_{3}{ }^{2-}$ anions (see Supplementary Figs. 6-8). It is noteworthy that $\left[\mathbf{L}_{2} \mathrm{Zn}_{3}\right]^{6+}$ pre-encapsulated with $\mathrm{PO}_{4}{ }^{3-}$ resulted in similar potencies, except against MCF10A cells, to $\left[\mathrm{L}_{2} \mathrm{Zn}_{3}\right]^{6+}$ alone. Due to significant quantities of phosphate in the cell culture media $(\sim 1$ $\mathrm{mM})$, it is likely that $\left[\mathrm{L}_{2} \mathrm{Zn}_{3}\right]^{6+}$ would encapsulate $\mathrm{PO}_{4}{ }^{3-}$ to form $\left[\mathrm{L}_{2} \mathrm{Zn}_{3}\left(\mathrm{PO}_{4}\right)\right]^{3+}$. Interestingly, however, the media used to culture MCF10A cells (Eagles MEM) contains more sulfate and lower amounts of phosphate than the culture media for most of the other cell lines and this may affect speciation and activity. In contrast, the pre-encapsulated sulfate and phenyl phosphate derivatives show some clear differences in potency and selectivity to $\left[\mathbf{L}_{2} Z_{3}\right]^{6+}$ depending on the cell line. Studies using ${ }^{31} \mathrm{P}$ NMR demonstrates that, whilst phosphate is present in the media, this anion does not entirely displace the pre-encapsulated anion and in a competitive experiment $\left[\mathrm{L}_{2} \mathrm{Zn}_{3}\left(\mathrm{SO}_{4}\right)\right]^{4+}$ is still the major species (see Supplementary Fig. 4.6). The mechanistic basis for these differential effects requires further investigation. However, these results demonstrate that the activity of these complexes can be readily modulated or potentially 'tuned' towards different cancer cells by altering the metal and/or the anion providing an inherently flexible platform for drug discovery.

Mechanistic kinase studies. Given the ability of the $\mathrm{Zn}^{2+}$ complex to dephosphorylate amino acids serine, tyrosine and threonine (Fig. 4) and the $\mathrm{Cu}^{2+}$ complex to bind phenyl phosphate (Fig. 3), this led us to examine whether the complexes affect the activity of kinases. This was assessed in a cell-free screen of 140 kinases using purified recombinant human kinases and substrate peptides incubated in the presence of ${ }^{33} \mathrm{P}$ ATP and $10 \mu \mathrm{M}$ complex or solvent control. $\left[\mathbf{L}_{2} \mathrm{Zn}_{3}\right]^{6+}$ and $\left[\mathbf{L}_{2} \mathrm{Cu}_{3}\right]^{6+}$ inhibited the activity of multiple kinases to differing extents, with the most potently inhibited kinases being inhibited by near to $100 \%$ (Fig. 7a, b, Supplementary Fig. 10). 

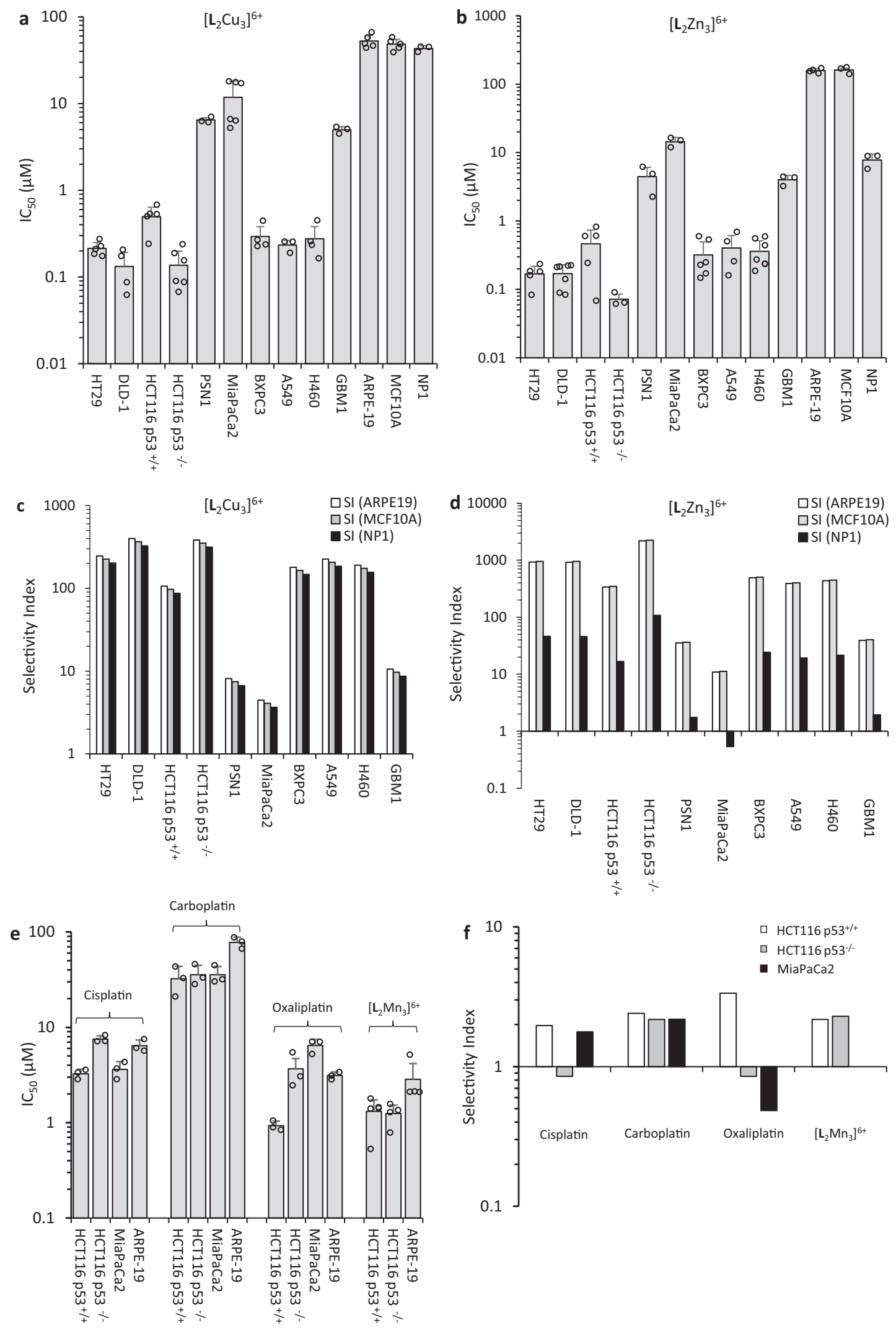

$\left[\mathrm{L}_{2} \mathrm{Cu}_{3}\right]^{6+}$ has inhibitory activity against a larger number of kinases than $\left[\mathbf{L}_{2} \mathrm{Zn}_{3}\right]^{6+}$ (Supplementary Fig. 10) which may reflect the fact that selectivity indices for $\left[\mathrm{L}_{2} \mathrm{Cu}_{3}\right]^{6+}$ are comparatively lower than those for $\left[\mathbf{L}_{2} \mathrm{Zn}_{3}\right]^{6+}$. In some cases, there is selective inhibition of

specific kinases by either $\left[\mathbf{L}_{2} \mathrm{Zn}_{3}\right]^{6+}$ or $\left[\mathbf{L}_{2} \mathrm{Cu}_{3}\right]^{6+}$ (Supplementary Fig. 10). For a few kinases, activity was increased by $\left[\mathbf{L}_{2} \mathrm{Cu}_{3}\right]^{6+}$ or $\left[\mathbf{L}_{2} \mathrm{Zn}_{3}\right]^{6+}$ (Fig. $\left.7 \mathrm{c}, \mathrm{d}\right)$, the most striking example being that of the proto-oncogene Src, a non-receptor tyrosine kinase ${ }^{40}$. Across the 
Fig. 5 Chemosensitivity response of a panel of human cancer and non-cancer cell lines to $\mathbf{9 6} \mathbf{h}$ continuous exposure to self-assembling test compounds. a, b The potency of compounds tested against cancer (HT-29, DLD-1, HCT116 p53 $+/+$ and p53-/-, PSN1, MiaPaCa2, BxPC3, A549, H460 and GBM1) and non-cancer cells (ARPE-19, MCF10A and NP1). Each value represents the mean $\mathrm{CC}_{50} \pm$ SD from a minimum of three independent experiments. The selectivity index $(\mathrm{SI})$ for $\left[\mathrm{L}_{2} \mathrm{Cu}_{3}\right]^{6+}(\mathbf{c})$ and $\left[\mathrm{L}_{2} \mathrm{Zn}_{3}\right]^{6+}(\mathbf{d})$ for the indicated cancer cell lines; $\mathrm{SI}$ is defined as the mean $\mathrm{IC}_{50}$ against the particular non-cancer cell line model divided by the mean $\mathrm{IC}_{50}$ against the particular cancer cell line. $\mathrm{SI}$ values $>1$ indicate that the test compound is more active against the particular cancer cell line than the corresponding non-cancer cells. As the $\mathrm{SI}$ value is calculated using the mean IC ${ }_{50}$ values, experimental error is not included in these figures. e I $C_{50}$ values for the clinically approved platinates (cisplatin, oxaliplatin and carboplatin) and $\left[L_{2} M_{3}\right]^{6+}(n=a$ minimum of three independent experiments and each value represents the mean $I_{50} \pm S D$ from a minimum of three independent experiments) and $\mathbf{f}$ the corresponding SI results.
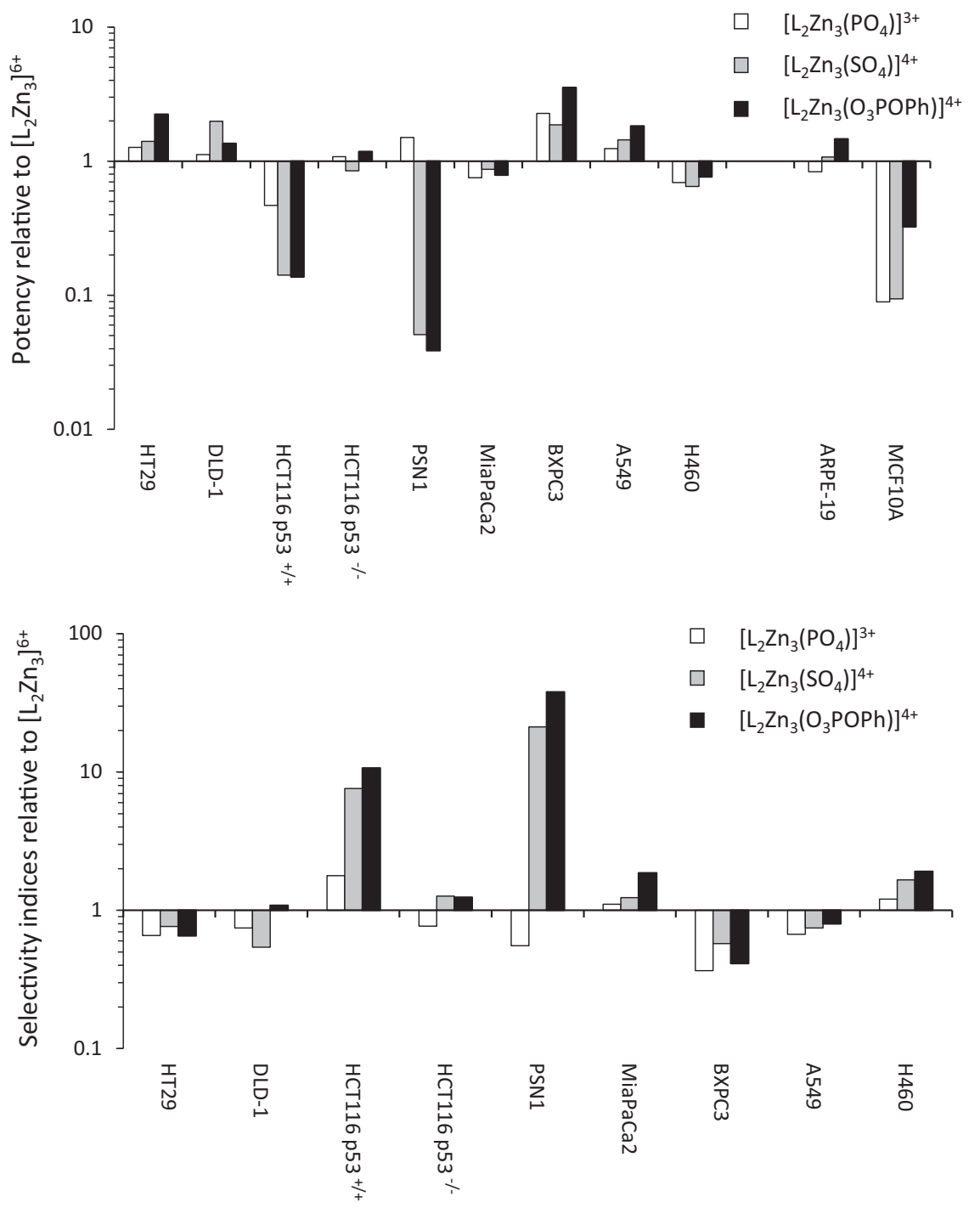

Fig. 6 Effect of the complex anion on potency and selectivity. a The effect of various anions on the potency of the $\mathrm{Zn}^{2+}$ complex; this is expressed as relative potency which is defined as the $I C_{50}$ of $\left[\mathbf{L}_{2} Z n_{3}\left(P_{4}\right)\right]^{3+},\left[\mathbf{L}_{2} Z_{n_{3}}\left(\mathrm{SO}_{4}\right)\right]^{4+}$ or $\left[\mathbf{L}_{2} Z n_{3}\left(O_{3} P O P h\right)\right]^{4+}$ divided by the $I C_{50}$ of $\left[\mathbf{L}_{2} Z n_{3}\right]^{6+}($ values $<1$ and $>1$ indicate increased and decreased potency respectively). $\mathbf{b}$ Effects of the anion on selectivity; these results are expressed as relative $\mathrm{SI}$ defined as the $\mathrm{SI}$ of $\left[\mathbf{L}_{2} \mathrm{Zn}_{3}\left(\mathrm{PO}_{4}\right)\right]^{3+},\left[\mathbf{L}_{2} \mathrm{Zn}_{3}\left(\mathrm{SO}_{4}\right)\right]^{4+}$ or $\left[\mathbf{L}_{2} \mathrm{Zn}_{3}\left(\mathrm{O}_{3} \mathrm{POPh}\right)\right]^{4+}$ divided by the $\mathrm{SI}$ of $\left[\mathbf{L}_{2} \mathrm{Zn}_{3}\right]^{6+}$ (values $>1$ and $<1$ indicate increased and decreased selectivity respectively).

kinome, we observed inhibition of kinases in the TK and CAMK family for $\left[\mathbf{L}_{2} \mathrm{Zn}_{3}\right]^{6+}$ and the CAMK and AGC family for $\left[\mathrm{L}_{2} \mathrm{Cu}_{3}\right]^{6+}$ (Fig. $\left.7 \mathrm{e}, \mathrm{f}\right)$, however whether this reflects an overall preference of the compounds requires further investigation.

Kinases are a major cellular drug target in the oncology field with the majority of kinase inhibitors that are clinically approved being ATP competitive inhibitors ${ }^{41}$. Against human AMPKa as one of the most potently inhibited kinases in the screen, assays showed both $\left[\mathbf{L}_{2} \mathrm{Cu}_{3}\right]^{6+}$ and $\left[\mathrm{L}_{2} \mathrm{Zn}_{3}\right]^{6+}$ complexes to be neither ATP competitive kinase inhibitors nor substrate competitive inhibitors (Fig. 7g, h) suggesting a non-competitive allosteric mechanism of kinase inhibition.

Other potential mechanisms were considered for the kinase screen inhibition 'read-out' including, i) direct ATP hydrolysis by the complex(es) and differing $\mathrm{Km}$ of the kinases for ATP, and, ii) dephosphorylation of the peptide substrate by the phosphatase 

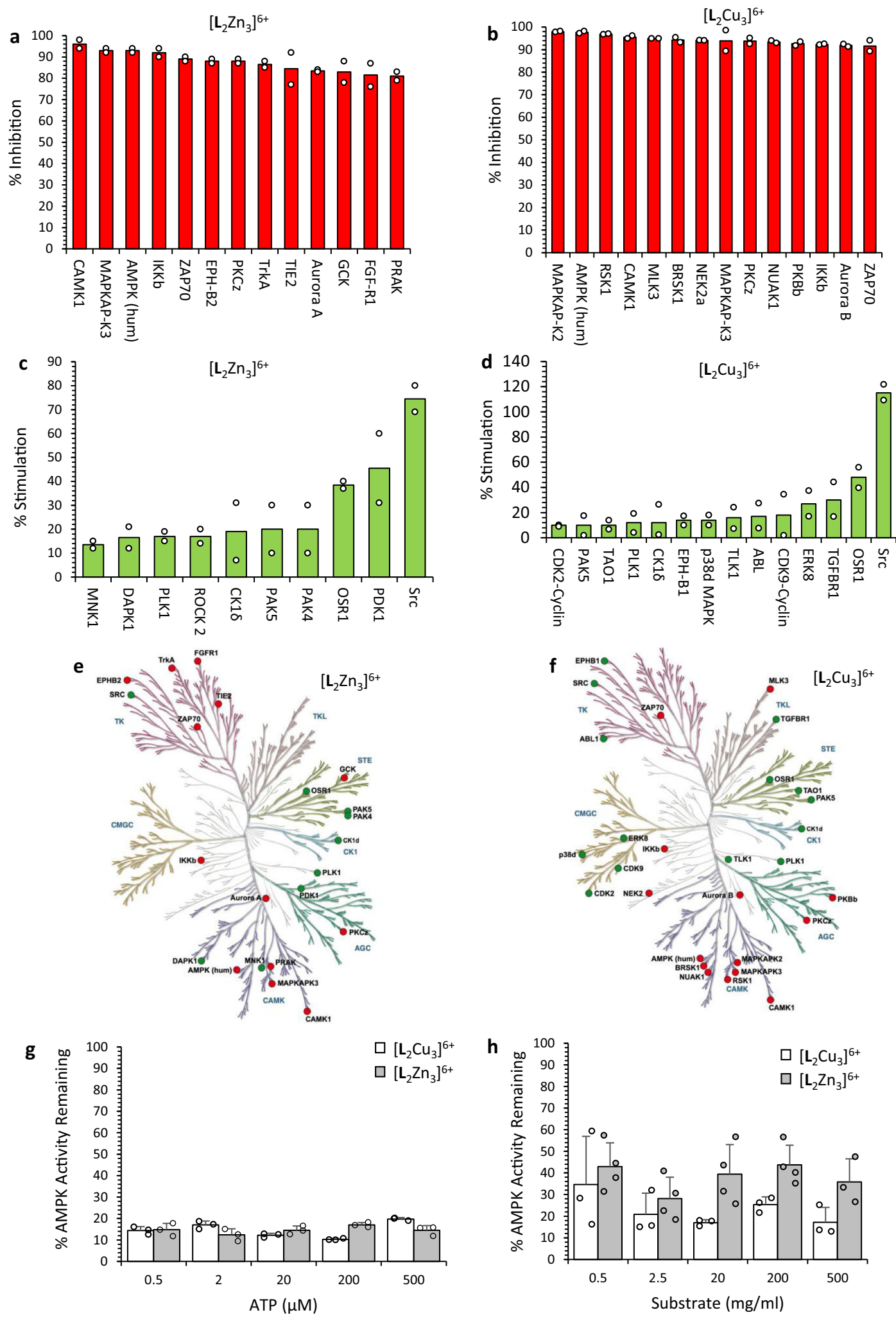

Fig. 7 Effects of $\left[\mathbf{L}_{2} \mathbf{Z n}_{3}\right]^{\mathbf{6}+}$ and $\left[\mathbf{L}_{2} \mathbf{C u}_{3}\right]^{\mathbf{6}+}$ on the activity of purified human kinases. Percentage inhibition (red) of the indicated kinases by $\left[\mathbf{L}_{2} Z n_{3}\right]^{6+}(\mathbf{a})$ and $\left[\mathbf{L}_{2} \mathrm{Cu}_{3}\right]^{6+}(\mathbf{b})$ respectively at a concentration of $10 \mu \mathrm{M}(n=2)$; full results are presented in the ESI. Kinases whose activity is stimulated (green) by $\left[\mathbf{L}_{2} Z_{3}\right]^{6+}(\mathbf{c})$ or $\left[\mathbf{L}_{2} \mathrm{Cu}_{3}\right]^{6+}(\mathbf{d})$ complexes. Kinome map showing kinases inhibited (red) or stimulated (green) by $\left[\mathbf{L}_{2} Z n_{3}\right]^{6+}(n=2)(\mathbf{e})$ or $\left[\mathbf{L}_{2} C u_{3}\right]^{6+}(\mathbf{f})$. Illustration reproduced courtesy of Cell Signalling Technology Inc (www.cellsignal.com). $\mathbf{g}$, $\mathbf{h}$ AMPK kinase inhibition by $\left[L_{2} Z n_{3}\right]^{6+}$ or $\left[L_{2} C_{3}\right]^{6+}$ is noncompetitive with ATP or substrate. $\mathbf{g}$ Influence of increasing ATP concentration (0.5-500 $\mu \mathrm{M})$ on the inhibition of AMPK kinase activity by $\left[\mathbf{L}_{2} Z \mathrm{n}_{3}\right]^{6+}$ or $\left[\mathbf{L}_{2} \mathrm{Cu}_{3}\right]^{6+}$ with the percentage of remaining kinase activity at each tested ATP concentration indicated. $\mathbf{h}$ Influence of increasing substrate concentration $(1-15 \mathrm{mg} / \mathrm{ml})$ on the inhibition of AMPK kinase activity by $\left[\mathbf{L}_{2} \mathrm{Zn}_{3}\right]^{6+}$ or $\left[\mathbf{L}_{2} \mathrm{Cu}_{3}\right]^{6+}$ with the percentage of remaining kinase activity at each tested substrate concentration indicated. Results in $\mathbf{g}$ and $\mathbf{h}$ are presented as mean \pm SD from a minimum of three independent biological repeats. 
activity of the $\mathrm{Zn}^{2+}$ complex resulting in cycles of peptide phosphorylation by active recombinant enzyme and dephosphorylation by the complex. However, mass spectroscopy showed little or no hydrolysis of ATP when incubated with $\mathrm{Zn}^{2+}$ or $\mathrm{Cu}^{2+}$ complex alone (Supplementary Fig. 2.30). Similarly, neither complex resulted in dephosphorylation of a purified phosphorylated AMPK peptide substrate (see Supplementary Fig. 4.3).

A plausible alternative explanation of the observed effects which can be reconciled with both selective kinase inhibition and activation is that that the $\mathrm{Zn}^{2+}$ and $\mathrm{Cu}^{2+}$ complexes are modulating key regulatory phospho-sites on the kinases themselves leading to enhanced or repressed kinase activity. In the case of the $\mathrm{Zn}^{2+}$ complex, dephosphorylation of specific phosphorylated regulatory amino acids through its phosphatase activity (Fig. 4) may lead to either kinase inhibition or activation. For the $\mathrm{Cu}^{2+}$ complex, it was hypothesised that it may bind to specific phosphorylated amino acids given its ability to bind but not hydrolyse phenyl phosphate (Fig. 3). This could affect kinase activity through influencing docking or binding of other proteins (e.g. SH2- domain-containing activating or inhibitory proteins $)^{42}$ or through steric or structural effects. One possible mechanism of kinase inhibition by either complex not formally investigated is the blocking of ADP release or it may be that multiple mechanisms contribute to the observed kinase inhibition or activation depending on the particular kinase.

To investigate these hypotheses further, regulatory phosphoamino acids of two key kinases identified by the kinase screen, AMPK and Src, were analysed following incubation of the recombinant kinases with $\mathrm{Zn}^{2+}$ or $\mathrm{Cu}^{2+}$ complexes. Phosphorylation of AMPKa at threonine 172 (T172P) stimulates AMPK activity ${ }^{43}$ and treatment of AMPK with either $\left[\mathbf{L}_{2} Z_{n_{3}}\right]^{6+}$ or $\left[\mathbf{L}_{2} \mathrm{Cu}_{3}\right]^{6+}$ significantly reduced T172P levels detectable by immunoblotting at a molecular weight of $\sim 63 \mathrm{kDa}$ (Fig. 8a).

Decreased T172P is consistent with the inhibition of AMPK by both $\left[\mathbf{L}_{2} \mathrm{Zn}_{3}\right]^{6+}$ and $\left[\mathbf{L}_{2} \mathrm{Cu}_{3}\right]^{6+}$ observed in the kinase screen (Fig. 7a, b) but subtle differences in effects of the $\left[\mathbf{L}_{2} \mathrm{Zn}_{3}\right]^{6+}$ and $\left[\mathbf{L}_{2} \mathrm{Cu}_{3}\right]^{6+}$ are revealed. In the case of $\left[\mathbf{L}_{2} \mathrm{Cu}_{3}\right]^{6+}$, high molecular weight bands of $>250 \mathrm{kDa}$ are detected with the T172P specific AMPKa antibody suggesting that this compound is binding to the kinase, consistent with its ability to bind or encapsulate phosphoanionic molecules as demonstrated in Fig. 3. $\left[\mathbf{L}_{2} \mathrm{Zn}_{3}\right]^{6+}$ on the other hand causes a clear reduction in T172P and no high molecular weight bands consistent with phosphatase activity towards this phosphorylated amino acid of recombinant AMKPa (Fig. 4). These effects of $\left[\mathbf{L}_{2} Z_{3}\right]^{6+}$ are not restricted to T172P of AMPKa, with phosphorylated levels of S108 of the non-catalytic AMPK $\beta$ subunit also decreasing following incubation with $\left[\mathbf{L}_{2} \mathrm{Zn}_{3}\right]^{6+}$ in a time- and concentration- dependent manner (Supplementary Fig. 11). Phosphorylation of S108 of AMPK $\beta$ increases AMPK activity ${ }^{44}$ indicating at least two potential mechanisms by which $\left[\mathbf{L}_{2} \mathrm{Zn}_{3}\right]^{6+}$ can inhibit AMPK kinase activity (Fig. 7a, g, h).

For Src, effects of the complexes on the key regulatory phosphoamino acids Y527 and Y416 were examined (Fig. 8a). Phosphorylation at Y527 in the Src C-terminal domain is known to decrease Src activity whereas autophosphorylation at Y416 in the activation loop of the kinase domain increases Src activity ${ }^{40,45}$. Here, incubation of recombinant $\operatorname{Src}$ with $\left[\mathrm{L}_{2} \mathrm{Zn}_{3}\right]^{6+}$ resulted in a $\sim 30 \%$ decrease in Y527P relative to total Src levels and a $\sim 5$-fold increase in Y416P levels (Fig. 8a), both of which combined would be expected to result in enhanced Src kinase activity as was observed in the kinase screen (Fig. 7c, d). The decrease in Y527P is consistent with selective phosphatase activity of $\left[\mathrm{L}_{2} \mathrm{Zn}_{3}\right]^{6+}$. Y527 dephosphorylation reduces allosteric inhibition of Src kinase activity by the C-terminal domain, enabling autophosphorylation a
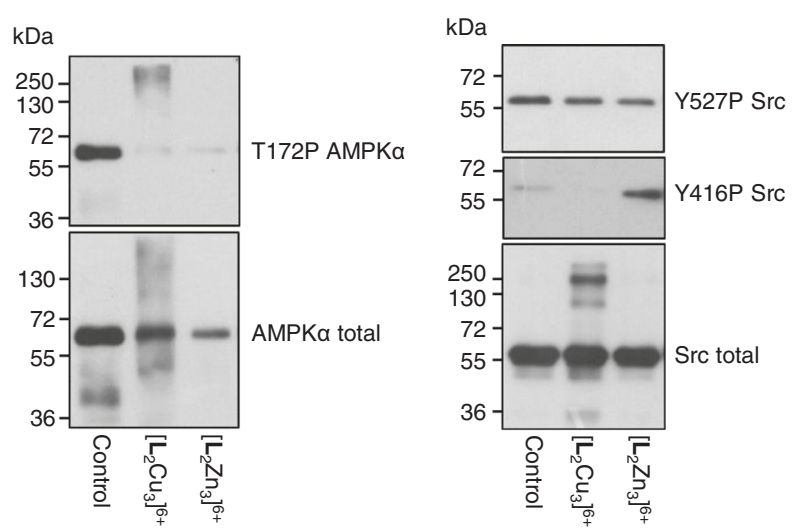

b

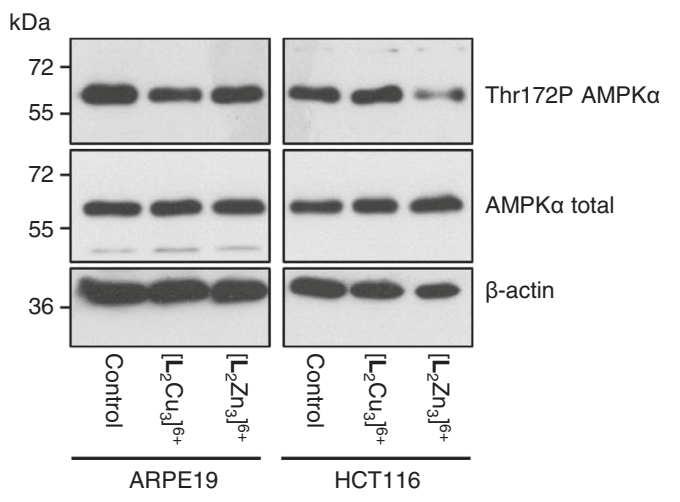

Fig. 8 Western blot analysis of purified recombinant AMPK and Src following exposure to $\left[\mathrm{L}_{2} \mathrm{Zn}_{3}\right]^{6+}$ and $\left[\mathrm{L}_{2} \mathrm{Cu}_{3}\right]^{6+}$ and the effects of $\left[\mathrm{L}_{2} \mathrm{Zn}_{3}\right]^{6+}$ and $\left[\mathrm{L}_{2} \mathrm{Cu}_{3}\right]^{6+}$ treatment on cellular phospho-Thr172 AMPKo levels. a Purified AMPK and Src enzymes were incubated with complexes $(50 \mu \mathrm{M})$ for $4 \mathrm{~h}$ in the presence of ATP prior to analysis. b ARPE-19 noncancer cells and HCT116 cancer cells were treated with $10 \mu \mathrm{M}\left[\mathrm{L}_{2} \mathrm{Cu}_{3}\right]^{6+}$ or $\left[\mathrm{L}_{2} \mathrm{Zn}_{3}\right]^{6+}$ for $4 \mathrm{~h}$ prior to harvesting and immunoblot analysis. Similar results were obtained in a minimum of $n=2$ independent experiments.

of Src at $\mathrm{Y} 416^{40}$. Similar to AMPK, incubation of $\left[\mathbf{L}_{2} \mathrm{Cu}_{3}\right]^{6+}$ with Src resulted in higher molecular weight bands detected with the total Src antibody which were not observed with control or $\left[\mathrm{L}_{2} \mathrm{Zn}_{3}\right]^{6+}$ treatments, suggesting binding of $\left[\mathrm{L}_{2} \mathrm{Cu}_{3}\right]^{6+}$ to Src. Y416P could not be detected raising the possibility that $\left[\mathrm{L}_{2} \mathrm{Cu}_{3}\right]^{6+}$ binding to Src masks detection of this epitope, however, further studies are required to unravel the detailed mechanism as to how $\left[\mathbf{L}_{2} \mathrm{Cu}_{3}\right]^{6+}$ binding to Src may increase its activity.

Intracellular $\left[\mathrm{L}_{2} \mathrm{Zn}_{3}\right]^{6+}$ and decreased cellular phospho-Thr172 AMPKa. Many of the kinases inhibited or activated in the cellfree kinase screen are intracellular raising the important question as to whether $\left[\mathbf{L}_{2} \mathrm{Zn}_{3}\right]^{6+}$ complexes are actually able to enter cells to potentially access these kinases or whether they exert their selective anti-cancer effects outside of the cell or at the cell membrane. The cell permeable Zn-binding dye $\mathrm{TSQ}^{46}$ was used as a surrogate marker to assess presence of $\left[\mathrm{L}_{2} \mathrm{Zn}_{3}\right]^{6+}$ within cells and whether there were any differences in levels or localisation between the chemoresistant ARPE-19 non-cancer and the chemosensitive HCT116 p53 $3^{+/+}$cancer cell line. The results indicate that the complex is taken up by both cell lines suggesting that differential chemosensitivity is unlikely to be caused by differential drug uptake (Supplementary Fig. 16). It also suggests that $\left[\mathbf{L}_{2} \mathrm{Zn}_{3}\right]^{6+}$ is able to directly access and potentially interact with, 
or dephosphorylate, at least some of the intracellular kinases that it inhibits or activates in the cell-free kinase screen. We cannot, however, currently exclude the possibility that anti-cancer activity of the complexes may be exerted without the complexes entering the cells, for example by the complexes transiently interacting with kinases located at the cell membrane (e.g. receptor tyrosine kinases) affecting downstream phospho-signalling. Analyses of cellular phospho-Thr172 AMPKa levels following $4 \mathrm{~h}$ treatment with $10 \mu \mathrm{M}\left[\mathbf{L}_{2} \mathrm{Cu}_{3}\right]^{6+}$ or $\left[\mathbf{L}_{2} \mathrm{Zn}_{3}\right]^{6+}$ revealed decreased T172P AMPKa selectively in the HCT116 cancer cells with $\left[\mathbf{L}_{2} Z_{n_{3}}\right]^{6+}$ treatment (Fig. 8b).

Selective induction of autophagy and cancer cell ATP depletion. Given the kinase screen results indicating that the $\left[\mathrm{L}_{2} \mathrm{Cu}_{3}\right]^{6+}$ and $\left[\mathbf{L}_{2} \mathrm{Zn}_{3}\right]^{6+}$ complexes can inhibit multiple kinases as well as activating several others (Fig. 7 and see Supplementary Fig. 10) and the common dysregulation of phospho-signalling in cancers ${ }^{38,47}$, this provides a plausible mechanism by which they might exert their cancer selective activity. Phenotypically, by $40 \mathrm{~h}\left[\mathbf{L}_{2} \mathrm{Zn}_{3}\right]^{6+}$ induced the appearance of vacuoles in the HCT116 p53 $3^{+/+}$and $\mathrm{p} 53^{-/-}$ cancer cells which were shown to be autophagic using the established autophagic tracer dye CYTO- $\mathrm{ID}^{48}$. The $\mathrm{Mn}^{2+}$ complex also induced autophagy whereas $\left[\mathbf{L}_{2} \mathrm{Cu}_{3}\right]^{6+} \operatorname{did}$ not (Fig. 9a and see Supplementary Figs. 13-15).

Autophagy is a catabolic process that is induced in response to metabolic stresses including low ATP levels and starvation ${ }^{43}$. We hypothesised that the induction of autophagy by $\mathrm{Zn}^{2+}$ and $\mathrm{Mn}^{2+}$ complexes could be due to cellular ATP depletion resulting from their protein phosphatase activity and repeated futile cycles between protein phosphorylation by constitutively active oncogenic kinases ${ }^{47}$ and dephosphorylation by the complexes. In support of this hypothesis, $\mathrm{Zn}^{2+}$ and $\mathrm{Mn}^{2+}$ complexes both caused a dosedependent decrease in ATP levels (Fig. 9b and see Supplementary Fig. 17). This was much more pronounced in the HCT116 cancer cells than in ARPE-19 non-cancerous cells with $\left[\mathbf{L}_{2} \mathrm{Zn}_{3}\right]^{6+}$, indicating cancer selective ATP depletion correlating with the excellent cancer cell selectivity indices of the $\mathrm{Zn}^{2+}$ complex (Fig. 5d). There was less difference in the magnitude of ATP depletion between the HCT116 cancer cells and the ARPE-19 noncancer cells with $\mathrm{Mn}^{2+}$ complex treatment (see Supplementary Fig. 17), consistent with its more modest selectivity indices (Fig. 5f). This may relate to more promiscuous phosphatase activity of the $\mathrm{Mn}^{2+}$ complex or its higher rates of hydrolysis (see Supplementary Fig. 5.1.). Another possibility, however, for the observed ATP depletion (Fig. 9b) is decreased ATP generation through the inhibition of glycolysis and/or mitochondrial respiration by the complexes. $1 \mathrm{~h}$ treatment with $25 \mu \mathrm{M}\left[\mathrm{L}_{2} \mathrm{Zn}_{3}\right]^{6+}$ caused a modest selective decrease in glycolysis in the HCT116 cancer cells whilst the more metabolically quiescent ARPE-19 cells were unaffected (Fig. 9c). $20 \mathrm{~h}$ treatment substantially impaired both mitochondrial respiration and glycolysis in the HCT116 cancer cells (Fig. 9d), likely contributing to the decrease in ATP levels.

It is currently unclear whether the effects of $\left[\mathrm{L}_{2} \mathrm{Zn}_{3}\right]^{6+}$ on glycolysis and mitochondrial respiration are linked to its phosphatase/kinase inhibitory activity or are via an independent mechanism. A number of key metabolic enzymes are kinases themselves (e.g. hexokinase, pyruvate kinase, phosphoglycerate kinase $)^{49}$ whilst others are regulated by phosphorylation (e.g. pyruvate dehydrogenase, lactate dehydrogenase A (LDH-A)). $\left[\mathbf{L}_{2} \mathrm{Zn}_{3}\right]^{6+}$ was found to modestly decrease p-Y10 LDH-A (phosphorylation of Y10 increases LDH-A activity) in ARPE-19 cells and to a lesser extent in HCT116 cells (see Supplementary Fig. 18).

Immunoblot analyses suggest that the observed autophagy (Fig. 9a) is a compensatory catabolic response to sustain ATP levels and prevent bioenergetic failure and death with $40 \mathrm{~h} 5 \mu \mathrm{M}$ $\left[\mathrm{L}_{2} \mathrm{Zn}_{3}\right]^{6+}$ inducing activation of the 'low ATP' sensing kinase $\mathrm{AMPK}^{43}$ in HCT116 cancer cells but not in ARPE-19 non-cancer cells (Fig. 10).

Thus, cellular levels of T172P of AMPKa were increased relative to total AMPKa levels specifically in the HCT116 cancer cells by $\left[\mathbf{L}_{2} \mathrm{Zn}_{3}\right]^{6+}$ but not by $\left[\mathbf{L}_{2} \mathrm{Cu}_{3}\right]^{6+}$ (Fig. 10). T172 AMPKa phosphorylation is induced by low cellular ATP levels and increased AMP or ADP levels, enabling competitive binding of AMP/ADP to the $\gamma$ regulatory subunit of AMPK enabling AMPKa phosphorylation by one of the AMPK upstream kinases ${ }^{43}$. Thus, paradoxically, $\left[\mathbf{L}_{2} \mathrm{Zn}_{3}\right]^{6+}$ causes dephosphorylation of T172 AMPKa and kinase inhibition in a cell-free system (Fig. 7a, g, h) and in the HCT116 cancer cells with brief exposure (Fig. 8b) consistent with its phosphatase activity (Fig. 4) but longer treatment results in increased cellular levels of T172P AMPK (Fig. 10) which is attributed to selective ATP depletion (Fig. 9b).

Following $\left[\mathbf{L}_{2} \mathrm{Zn}_{3}\right]^{6+}$ treatment of HCT116 cancer cells, a small decrease $(\sim 10 \%)$ in total levels of Tyr- phosphorylated proteins was detected by immunoblotting using a pan phospho-tyrosine antibody although there was also evidence of increased $\mathrm{p}-\mathrm{Y}$ of some proteins $(*)$ (Fig. 10). Importantly, both $\left[\mathbf{L}_{2} \mathrm{Cu}_{3}\right]^{6+}$ and $\left[\mathbf{L}_{2} \mathrm{Zn}_{3}\right]^{6+}$ treatment resulted in increased levels of the p53 tumour suppressor protein which is induced by many different types of cellular stress resulting in the co-ordination of an appropriate stress response which can include cell cycle arrest or cell death induction ${ }^{50}$. Whilst p53 levels were increased by $\sim 1.7$ fold by $\left[\mathbf{L}_{2} \mathrm{Cu}_{3}\right]^{6+}$ and $\sim 2.7$ fold by $\left[\mathbf{L}_{2} \mathrm{Zn}_{3}\right]^{6+}$ treatment in the HCT116 cancer cells, levels of p53 actually decreased with treatment in the ARPE19 non-cancer cells further indicating differential effects of the complexes on cancer versus non-cancer cells (Fig. 10). The earlier chemosensitivity results indicate, however, that the cytotoxicity of the $\left[\mathbf{L}_{2} \mathrm{Cu}_{3}\right]^{6+}$ and $\left[\mathbf{L}_{2} \mathrm{Zn}_{3}\right]^{6+}$ is not dependent on $\mathrm{p} 53$; indeed both complexes were more active towards the HCT116 $\mathrm{p} 53^{-/-}$cells than the isogenic $\mathrm{p} 53^{+/+}$cells (Fig. 5a).

In summary, in this study three different metal-containing, self-assembled anion binding complexes are characterised and shown to have distinctive chemical and biological properties. Depending on the metal, the reactivity of the complexes towards different anionic species varied with the $\mathrm{Zn}^{2+}$ and $\mathrm{Mn}^{2+}$ complexes both showing significant phosphatase activity but with different rates of hydrolysis $\left(\mathrm{Mn}^{2+}>>\mathrm{Zn}^{2+}\right)$ whereas the $\mathrm{Cu}^{2+}$ complex bound to, rather than hydrolysed, phosphocontaining species. Significant selective activity towards particular cancer cells compared to non-cancer cells was shown by the $\mathrm{Zn}^{2+}$ and $\mathrm{Cu}^{2+}$ complexes by different mechanisms with evidence of modulation of multiple kinases via either binding $\left(\mathrm{Cu}^{2+}\right)$ or by de-phosphorylation $\left(\mathrm{Zn}^{2+}\right)$ of regulatory sites on kinases. Using an unbiased phospho-proteomics approach, future studies will aim to identify which phospho-sites on proteins are selectively dephosphorylated by $\left[\mathbf{L}_{2} \mathrm{Zn}_{3}\right]^{6+}$. This will include whether $\left[\mathbf{L}_{2} \mathrm{Zn}_{3}\right]^{6+}$ shows any activity towards phospho-serine/threonine proline motifs, a common regulatory motif in many signalling proteins. However, we cannot exclude the possibility of additional mechanisms contributing to the selective anti-cancer activity of $\left[\mathbf{L}_{2} \mathrm{Cu}_{3}\right]^{6+}$ and $\left[\mathbf{L}_{2} \mathrm{Zn}_{3}\right]^{6+} . \mathrm{Zn}^{2+}$ and $\mathrm{Mn}^{2+}$ complexes both induced cancer cell autophagy consistent with cellular ATP deficiency and bioenergetic failure. Further modulation of activity and selectivity profile by incorporation of different anions (e.g. $\mathrm{PO}_{4}{ }^{3-}, \mathrm{SO}_{4}{ }^{2-}$ or $\mathrm{PhOPO}_{3}{ }^{2-}$ ) pre-cell exposure indicates the ease of generating numerous 'modular' combinations of metal/anion binding self-assembling complexes that can differ in potency, selectivity and mechanism(s) of action towards disease. 
a

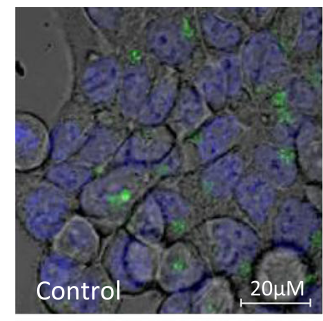

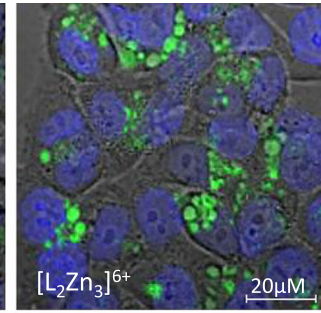

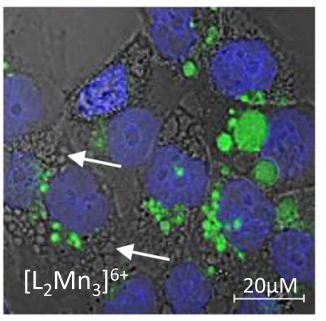

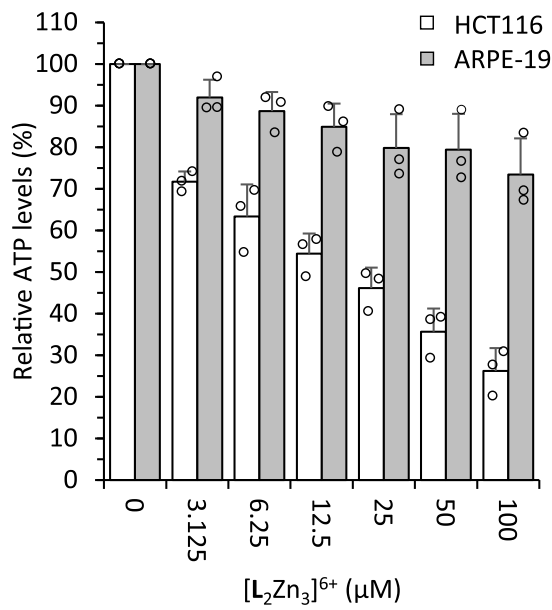

c

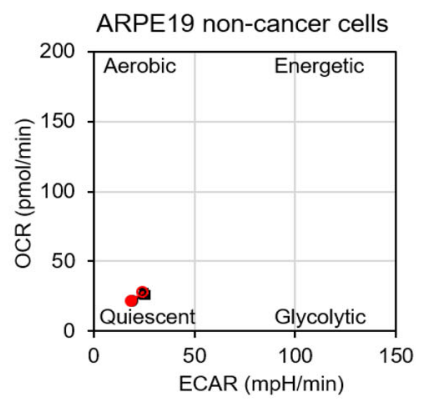

$\rightarrow$ control $\rightarrow 1 \mathrm{~h}\left[\mathrm{~L}_{2} \mathrm{Zn}_{3}\right]^{6+}$

d

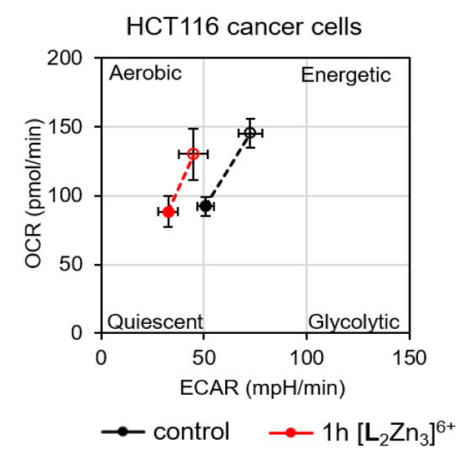

HCT116 cancer cells

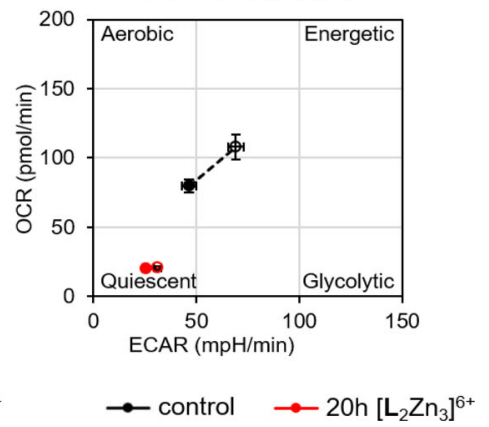

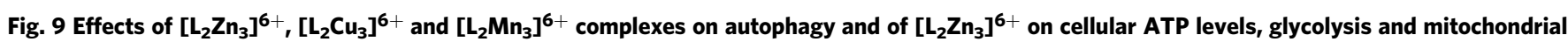

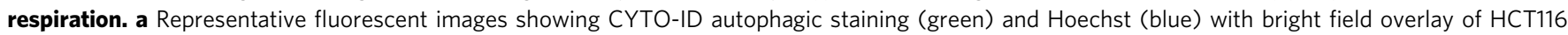
p53-/- cells treated with $3.125 \mu \mathrm{M}\left[\mathrm{L}_{2} \mathrm{Zn}_{3}\right]^{6+},\left[\mathrm{L}_{2} \mathrm{Cu}_{3}\right]^{6+}$ or $\left[\mathrm{L}_{2} \mathrm{Mn}_{3}\right]^{6+}$ for $40 \mathrm{~h}$. White arrows indicate intracellular vacuoles. Similar results were obtained in $n=3$ independent experiments. b, Cellular ATP levels in ARPE-19 non-cancer cells and HCT116 p53+/ cancer cells with 20 h exposure to $\left[\mathrm{L}_{2} \mathrm{Zn}_{3}\right]^{6+}$ at the indicated concentrations; ATP levels expressed relative to levels in vehicle control-treated cells. $n=3$ biologically independent experiments. Mean ATP levels \pm SD. c, d Metabolic phenograms showing cellular rate of oxygen consumption (OCR) as measure of mitochondrial respiratory rate and extracellular acidification rate (ECAR) as a measure of glycolytic rate in ARPE-19 and HCT116 cells (closed circles, basal metabolic rates). c Effect of $1 \mathrm{~h} 25 \mu \mathrm{M}\left[\mathrm{L}_{2} \mathrm{Zn}_{3}\right]^{6+}$, d Effect of $20 \mathrm{~h} 25 \mu \mathrm{M}\left[\mathrm{L}_{2} \mathrm{Zn}_{3}\right]^{6+}$. Open circles represent maximal ECAR and OCR (metabolic capacity/reserve) of control and $\left[\mathrm{L}_{2} \mathrm{Zn}_{3}\right]^{6+}$ treated cells, determined by addition of a metabolic stress mixture (oligomycin and FCCP). Black line/circle indicates vehicle control-treated cells; red line/circle indicates $\left[\mathrm{L}_{2} \mathrm{Zn}_{3}\right]^{6+}$ treated cells. $n=3$ independent experiments; mean $\pm \mathrm{SD}$.

\section{Methods}

Synthesis. Unless otherwise stated, all solvents and materials were purchased from either Sigma Aldrich, Fisher Scientific or Fluorochem and were used without further purification. ${ }^{1} \mathrm{H},{ }^{13} \mathrm{C}$, DEPT-135 and DEPT-90 NMR data was recorded on either a Bruker Fourier $300 \mathrm{MHz}$ or Bruker Avance III (AVIII) 400 $\mathrm{MHz}$ spectrometer or a Bruker Avance Neo $600 \mathrm{MHz}$ NMR spectrometer. Mass spectra were obtained on an Agilent 6210 TOF MS with electrospray ionisation operating in positive ion mode and mass spectra of metal complexes were obtained on a Bruker Micro TOF-q LC mass spectrometer with electrospray ionisation operating in positive ion mode. Phosphorylated 'SAMS' peptide
HMRSAMS*GLHLVKRR (*phosphorylated on the serine residue) was obtained from PeptideSynthetics, Peptide Protein Research Ltd ( $>95 \%$ purity). Elemental analysis was performed on an Exeter Analytical CE440 Elemental Analyser.

CAUTION: perchlorate anions are potentially explosive and should be treated with appropriate care. The complexes described were prepared and isolated only in small amounts $(5-10 \mathrm{mg})$.

Preparation of ligand $\mathbf{L}$ and its complexes. The synthetic route is described by Supplementary Fig. 1.1. The ligand was prepared by a modification of a literature 


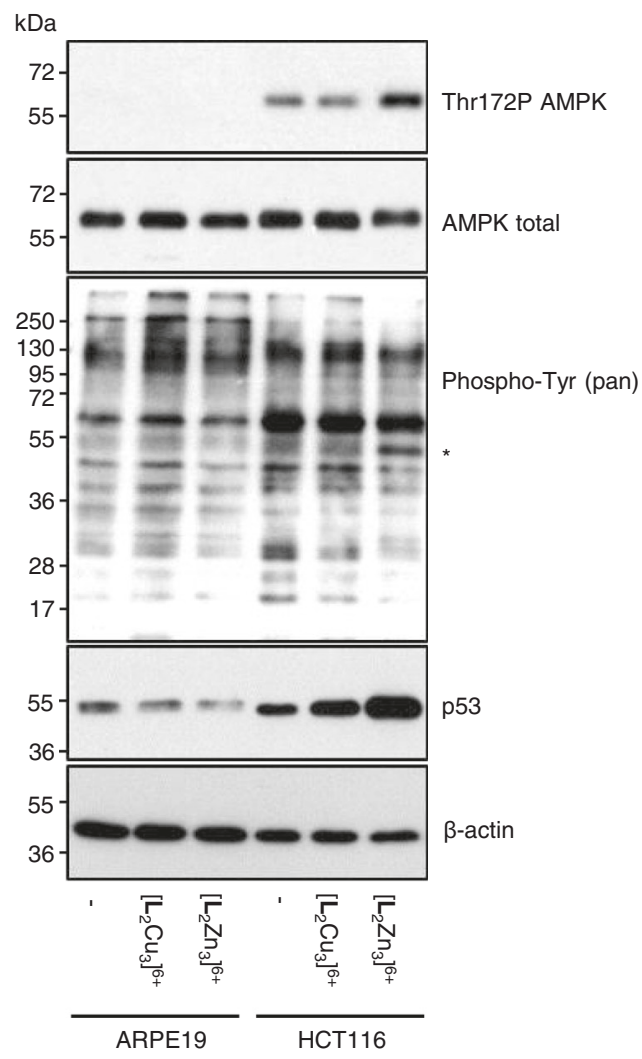

Fig. 10 Immunoblots showing the differential effects of $\left[\mathrm{L}_{2} \mathrm{Cu}_{3}\right]^{6+}$ and $\left[\mathrm{L}_{2} \mathrm{Zn}_{3}\right]^{6+}$ treatment of HCT116 cancer cells and ARPE-19 non-cancer cells on key cellular proteins associated with cellular and metabolic

stress. Representative immunoblot images of the indicated proteins following cell exposure to $5 \mu \mathrm{M}\left[\mathbf{L}_{2} \mathrm{Cu}_{3}\right]^{6+}$ or $\left[\mathbf{L}_{2} \mathrm{Zn}_{3}\right]^{6+}$ for $40 \mathrm{~h}$. Tyrosine phosphorylated proteins are indicated using a pan- phospho-Tyr antibody; $\beta$-actin as a loading control. Similar results were obtained in a minimum of $n=2$ independent experiments.

procedure and the analytical data was identical to that reported ${ }^{31}$. For the chemical studies the complexes were prepared by direct reaction of metal perchlorate or tetrafluoroborate salts in $\mathrm{MeCN}$ (or acetone) and $\mathrm{H}_{2} \mathrm{O}$ with the ligand. The anion host species were prepared by addition of either $\mathrm{Na}_{2} \mathrm{O}_{3} \mathrm{POPh}, \mathrm{Bu}_{4} \mathrm{NH}_{2} \mathrm{PO}_{4}$, $\mathrm{Bu}_{4} \mathrm{NHSO}_{4}$ to solutions of the complex. The purity and composition of the complexes was confirmed by ESI-MS, ${ }^{1} \mathrm{H} /{ }^{31} \mathrm{P}$ NMR (where applicable) and elemental analysis. For the cytotoxicity studies all the complexes were prepared from the metal acetates ${ }^{31}$.

$\mathbf{X}$-ray structural determination. Single crystals of the compounds analysed via this method were grown from slow evaporation of a solution of $\mathrm{MeCN} / \mathrm{H}_{2} \mathrm{O}$ (apart from $[\mathrm{LZn}]\left(\mathrm{ClO}_{4}\right)_{2}$ where a mixture of acetone $/ \mathrm{MeCN}$ was used). X-ray diffraction data was collected at $150(2) \mathrm{K}$ on a Bruker D8 Venture diffractometer equipped with a graphite monochromated $\mathrm{Mo}(\mathrm{K} \alpha)$ radiation source and a cold stream of $\mathrm{N}_{2}$ gas. Solutions were generated by conventional heavy atom Patterson or direct methods and refined by full-matrix least squares on all $F^{2}$ data, using SHELXS-97 (for solution), SHELXL-2014 (for refinement) and SHELXL (for molecular graphics) software respectively ${ }^{51}$. In some examples Olex2 was used in refinement ${ }^{52}$. Absorption corrections were applied based on multiple and symmetry-equivalent measurements using $\mathrm{SADABS}^{53}$. Almost all the structures contained some form of disorder either with solvent molecules and/or counter anions (generally substitutional or rotation disorder). In these cases, the atoms were modelled using the $P A R T$ instruction in the least squares refinement and refined over two positions. The anisotropic displacement parameters were treated with SIMU, DELU and in some cases ISOR where needed. Due to the diffuse nature of the electron density map the hydrogen atoms were not added to disordered solvent molecules. The structure $\left[\mathrm{L}_{2} \mathrm{Zn}_{3}\left(\mathrm{SO}_{4}\right)\right]\left(\mathrm{BF}_{4}\right)_{3.5}$ contained extensively disordered tetrafluoroborate counter anions, one of which refined poorly and was modelled with $50 \%$ occupancy.

NMR studies. For ${ }^{1} \mathrm{H}$ NMR studies, reaction of $\left[\mathrm{L}_{2} \mathrm{Zn}_{3}\right]^{6+}$ with either $\mathrm{Na}_{2} \mathrm{O}_{3} \mathrm{POPh}$ and $\mathrm{Bu}_{4} \mathrm{NH}_{2} \mathrm{PO}_{4}$ was carried out in $10 \% \mathrm{D}_{2} \mathrm{O}$ in $\mathrm{CD}_{3} \mathrm{CN}$. The NMR solutions were prepared by dissolving the ligand $\mathbf{L}$ and $\mathrm{Zn}\left(\mathrm{C}_{2} \mathrm{H}_{3} \mathrm{O}_{2}\right)_{2}$ (in a ratio of 1:1.5) in $\mathrm{CD}_{3} \mathrm{CN}(600 \mu \mathrm{L})$. The relevant anion $(0.5$ equivalents w.r.t ligand) was dissolved in $\mathrm{D}_{2} \mathrm{O}(60 \mu \mathrm{L})$ and these solutions were then combined. Heating of the sample was carried out @ $80^{\circ} \mathrm{C}$ in a water bath for the specified amount of time. For the ${ }^{31} \mathrm{P}$ NMR studies solutions were prepared by dissolving the ligand $\mathbf{L}$ and $\mathrm{Zn}\left(\mathrm{C}_{2} \mathrm{H}_{3} \mathrm{O}_{2}\right)_{2}$ (in a ratio of $1: 1.5)$ in $\mathrm{d}_{6}$-DMSO $(200 \mu \mathrm{L})$. The anion (0.5 equivalents w.r.t ligand) was dissolved in HEPES $(600 \mu \mathrm{L}, 60 \mathrm{mmol} @ p \mathrm{H} 7.4)$ and these solutions were then combined. Where required heating of the sample was carried out by incubating the sample @ $37^{\circ} \mathrm{C}$ and/or a further $2 \mathrm{~h} @ 80^{\circ} \mathrm{C}$ in a water bath.

UV-Vis studies. UV-Vis studies were carried out on a Cary 60 UV-Vis spectrophotometer with Thermo cycler attachment and the wavelength range of $800-250 \mathrm{~nm}$ was scanned every hour for $43 \mathrm{~h}$ whilst the solution was heated at a constant temperature of $37^{\circ} \mathrm{C}$. Progress of hydrolysation of 4-nitrophenyl phosphate to 4-nitrophenol was measured by monitoring the increase in absorption at the wavelength of $400 \mathrm{~nm}$ (typical for 4-nitrophenol). HEPES buffer was prepared at $p \mathrm{H}$ 7.4. Solutions were prepared by dissolving the ligand $\mathbf{L}(3.1 \mathrm{mg}, 0.005 \mathrm{mmol})$ and the relevant metal salt (1.5 equivalents with respect to ligand) in DMSO (5 $\mathrm{mL}$ ). 4-nitrophenyl phosphate $(18.6 \mathrm{mg}, 0.050 \mathrm{mmol})$ was dissolved in HEPES buffer $(\sim 10 \mathrm{~mL}, 60 \mathrm{mmol})$. These solutions were then combined and made up volumetrically to $50 \mathrm{~mL}$ with HEPES buffer. Where required $\mathrm{Bu}_{4} \mathrm{NH}_{2} \mathrm{PO}_{4}(0.5$ equivalents with respect to ligand) was added to the HEPES buffer.

Cell culture and chemosensitivity studies. All cell lines were purchased from and maintained as monolayers as described by the American Type Culture Collection with the exception of the $\mathrm{p} 53^{+/+}$and $\mathrm{p} 53^{-/-}$isogenic clones of HCT116 human colorectal adenocarcinoma cells which were a kind gift from Professor Bert Vogelstein ${ }^{54}$. GBM1 cells were established from a primary GBM tumour by Heiko Wurdak and colleagues ${ }^{32,33}$. Non-cancerous adult brain neural progenitor (NP1) cells were derived from a patient undergoing surgery to treat epilepsy ${ }^{32,33}$. Cell culture and growth media for NP1 and GBM1 cells were as described ${ }^{32,33}$. The response of cells following a continuous 96-h exposure to test compounds and platinates was determined using the MTT assay. Potency was recorded as the $\mathrm{IC}_{50}$ and the selectivity index (SI) was defined as the ratio of $\mathrm{IC}_{50}$ values for non-cancer to cancer cell lines with values $>1$ representing selectivity for cancer cells as opposed to non-cancer cells ${ }^{19}$.

Cell line origins and culture media. All cell lines used were maintained at low passage in antibiotic-free media. HT29, DLD-1, HCT116 p53 $3^{+/+}$and HCT116 $\mathrm{p} 53^{-/-}$ are all colorectal adenocarcinoma cell lines derived from different individuals and harbour different combinations of oncogenic lesions (except for the HCT116 isogenic cancer cell clones that are genetically identical except for p53 status). PSN-1, BxPC-3 and MiaPaCa2 are pancreatic carcinoma cell lines and A549 and H460 are lung carcinoma cell lines. HT29, DLD-1, PSN-1, BxPC-3, A549 and H460 cell lines were cultured in RPMI-1640 growth media (Sigma) containing $2 \mathrm{mM}$ L-glutamine, $1 \mathrm{mM}$ sodium pyruvate and $10 \%$ foetal bovine serum (FBS). HCT116 ( $\mathrm{p} 53^{+/+}$and $\left.\mathrm{p} 53^{-/-}\right)$ and MiaPaCa2 cell lines were cultured in Dulbecco's Modified Eagle's Medium (Sigma), $2 \mathrm{mM} \mathrm{L-glutamine}$ and 10\% FBS. The ARPE-19 retinal epithelial non-cancer cell line was cultured in DMEM/F12 media (Gibco), 2 mM L-glutamine, $1 \mathrm{mM}$ sodium pyruvate and $10 \%$ FBS. The MCF10A non-cancerous human breast epithelial cell line was cultured in Minimal Essential Media Eagle (Sigma), 2 mM L-glutamine, $1 \mathrm{mM}$ sodium pyruvate, $10 \% \mathrm{FBS}$ and $1 \mathrm{x}$ non-essential amino acids (NEAA). NP1 and GBM1 cells were cultured on plasticware coated with poly-L-ornithine $(5 \mu \mathrm{g} / \mathrm{ml})$ and laminin $(2.4 \mu \mathrm{g} / \mathrm{ml})^{32,33}$. NP1 cells were grown in DMEM/F12 media (Gibco) supplemented with 5\% FBS, $20 \mathrm{ng} / \mathrm{ml}$ hFGF, $20 \mathrm{ng} / \mathrm{ml}$ rhEGF, 0.5x B-27 supplement (Gibco), $0.5 \mathrm{x} \mathrm{N}-2$ supplement (Gibco) and 1x GLUTAMAX (Gibco). GBM1 cells were cultured in Neurobasal media (Gibco) supplemented with $40 \mathrm{ng} / \mathrm{ml} \mathrm{hFGF,} 40 \mathrm{ng} / \mathrm{ml}$ rhEGF, 0.5x B-27 supplement (Gibco) and 0.5x N-2 supplement (Gibco).

Cell seeding for chemosensitivity studies. $\left[\mathrm{L}_{2}(\mathrm{Metal})_{3}\right]^{6+}$ and all the other selfassembling complexes were freshly formed by adding DMSO to individual components and mixing together by pipetting. These were then further diluted in cell culture media such that the final DMSO concentration that cells were exposed to was $0.2 \%$ (vehicle control). Cisplatin, oxaliplatin and carboplatin were dissolved in phosphate buffered saline. Cell lines were seeded into 96 well plates at $2 \times 10^{3}$ cells per well and incubated overnight at $37^{\circ} \mathrm{C}$. GBM1 cancer stem-like cells were seeded at $3 \times 10^{3}$ cells per well and NP1 neural progenitors were seeded at $1.5 \times 10^{3}$ cells per well. The following day, media was removed and replaced with fresh media containing test compounds at a range of concentrations. Cells were incubated with test compounds for a further $96 \mathrm{~h}$ after which the media was removed and replaced with fresh media $(200 \mu \mathrm{l} /$ well $)$. MTT was added $(20 \mu \mathrm{l}$ at $5 \mathrm{mg} / \mathrm{ml})$ and cells were incubated for a further $4 \mathrm{~h}$. Media and MTT were removed and formazan crystals were dissolved in $150 \mu \mathrm{l}$ of DMSO and the absorbance of the resulting solution determined at $540 \mathrm{~nm}$. Dose response curves were constructed, and the concentration required to reduce cell growth by $50 \%\left(\mathrm{IC}_{50}\right)$ determined.

Kinase inhibition screen. $\left[\mathrm{L}_{2} \mathrm{Cu}_{3}\right]^{6+}$ and $\left[\mathbf{L}_{2} \mathrm{Zn}_{3}\right]^{6+}$ were submitted to the MRC Protein Phosphorylation and Ubiquitination Unit International Centre for Kinase Profiling (University of Dundee) and tested in duplicate (at $10 \mu \mathrm{M})$ against a series 
of 140 purified human kinases in a cell-free kinase assay using ${ }^{33} \mathrm{P}$ ATP 55,56 . The kinase gene IDs from the screen were then translated into common IDs (HGNC symbol) using biomaRt package ${ }^{57,58}$ in $\mathrm{R}^{59}$ and R Studio ${ }^{60}$ and used as input to the KinMap programme ${ }^{61}$. The KinMap output was then manually annotated to include the top activated and inhibited kinases as shown in Fig. 7.

ATP and substrate competition assays. ATP competition kinase assays were performed by the MRC Protein Phosphorylation and Ubiquitination Unit International Centre for Kinase Profiling (University of Dundee). Inhibition of recombinant human AMPK $(\alpha 1 \beta 2 \gamma 1)$ by $10 \mu \mathrm{M}\left[\mathbf{L}_{2} \mathrm{Cu}_{3}\right]^{6+}$ or $\left[\mathbf{L}_{2} \mathrm{Zn}_{3}\right]^{6+}$ was evaluated at five different ATP concentrations $(0.5,2,20,200$ and $500 \mu \mathrm{M}$ ATP). Substrate competition assays were performed using the ADP-Glo Kinase Assay (Promega) and recombinant human AMPK $(\alpha 1 \beta 2 \gamma 1)$ (Promega) with concentrations of the provided AMPK substrate (SAMStide substrate, Promega) ranging from 1 to $15 \mathrm{mg} / \mathrm{ml}$. Following pre-incubation of substrate with kinase for $5 \mathrm{~min}$ $10 \mu \mathrm{M}\left[\mathbf{L}_{2} \mathrm{Cu}_{3}\right]^{6+},\left[\mathbf{L}_{2} \mathrm{Zn}_{3}\right]^{6+}$ or solvent control and $50 \mu \mathrm{M}$ ATP was added to start the kinase reaction. For determination of the effects of AMP on AMPK inhibition by $\left[\mathbf{L}_{2} \mathrm{Zn}_{3}\right]^{6+}$, the ADP-Glo Kinase Assay (Promega) was performed in presence of varying of $\mathrm{AMP}(0,80,160 \mu \mathrm{M})$.

\section{In vitro phosphatase assay with recombinant kinases. $800 \mathrm{ng}$ of purified} recombinant human AMPK ( $\alpha 1 \beta 2 \gamma 1)$ or Src kinase (MRC PPU, International Centre for Kinase Profiling, University of Dundee) was incubated with $50 \mu \mathrm{M}$ $\left[\mathbf{L}_{2} \mathrm{Cu}_{3}\right]^{6+},\left[\mathbf{L}_{2} \mathrm{Zn}_{3}\right]^{6+}$, or vehicle control in $50 \mathrm{mM}$ Tris $\mathrm{HCl} \mathrm{pH} 7.5$ containing $50 \mu \mathrm{M}$ ATP for $4 \mathrm{~h}$ at $37^{\circ} \mathrm{C}$. For $\left[\mathrm{L}_{2} \mathrm{Zn}_{3}\right]^{6+}$ time course and concentration titration experiments, $800 \mathrm{ng}$ recombinant human AMPK was used $(\alpha 1 \beta 2 \gamma 1$ AMPK isoform for pT172 AMPKa1 detection or $\alpha 2 \beta 1 \gamma 1$ AMPK isoform for $\mathrm{pS} 108$ AMPK $\beta 1$ detection). For evaluation of ATP dependency and influence of AMP, $50 \mu \mathrm{M}$ ATP was replaced with $50 \mu \mathrm{M}$ AMP or omitted. Reactions were stopped by addition of Laemmli's buffer (Biorad) to $1 \mathrm{x}$ and heating at $95^{\circ} \mathrm{C}$ for $5 \mathrm{~min}$ before analysis by SDS PAGE and immunoblotting for detection of specific phosphorylated amino acids of AMPK and Src proteins.

Metabolic studies. ARPE-19 and HCT116 cells were seeded in 8-well XFp plates (Agilent) $48 \mathrm{~h}$ prior to metabolic flux analyses using the Agilent XFp extracellular flux analyser. Cell seeding densities were 2500 cells/well for ARPE-19 cells and 7500 cells/well for HCT116 cells in order to achieve equivalent cell confluency ( $\sim 70 \%$ confluency and in $\log$ phase growth) at the time of analyses. Cells were treated with $25 \mu \mathrm{M}$ of $\left[\mathrm{L}_{2} \mathrm{Zn}_{3}\right]^{6+}$ or solvent control $(0.2 \% \mathrm{DMSO})$ for $1 \mathrm{~h}$ or $20 \mathrm{~h}$ before metabolic flux analyses using the Cell Energy Phenotype Assay (Agilent) in accordance with the manufacturer's instructions. For determination of maximal respiratory and glycolytic rates (metabolic reserve) following real-time quantification of basal respiratory and glycolytic rates, a 'metabolic stress mix' of $1 \mu \mathrm{M}$ oligomycin and FCCP $(0.5 \mu \mathrm{M}$ for ARPE-19, $0.25 \mu \mathrm{M}$ for HCT116) was injected into the media.

Confocal microscopy imaging of autophagic cells. Cells were seeded in Lumox chamber slides (8-well, Sarstedt) at a density of $1.25 \times 10^{4}$ cells/well (ARPE-19) or $5.625 \times 10^{4}$ cells/well (HCT116 p53 $3^{-/-}$and HCT116 p53 $3^{+/+}$). $24 \mathrm{~h}$ after seeding, cells were treated with $3.125 \mu \mathrm{M}$ of $\left[\mathbf{L}_{2} \mathrm{Cu}_{3}\right]^{6+},\left[\mathbf{L}_{2} \mathrm{Zn}_{3}\right]^{6+},\left[\mathbf{L}_{2} \mathrm{Mn}_{3}\right]^{6+}$, or vehicle control for $40 \mathrm{~h}$ before removal and addition of CYTO-ID Green autophagic dye (1:500 dilution, Enzo Life Sciences) and Hoechst 3342 nuclear counter stain for 30 min at $37^{\circ} \mathrm{C}$. Media was then replaced before imaging using a Zeiss LSM880 confocal laser scanning microscope.

TSQ cellular localisation studies. $48 \mathrm{~h}$ following cell seeding in Lumox chamber slides (8-well, Sarstedt), cells (ARPE-19 and HCT116 p53 $53^{+/+}$were treated for $1 \mathrm{~h}$ at $37^{\circ} \mathrm{C}$ with $25 \mu \mathrm{M}$ of $\left[\mathbf{L}_{2} \mathrm{Zn}_{3}\right]^{6+}$ or DMSO solvent control before removal and washout three times using complete phenol-red free media. $25 \mu \mathrm{M}$ TSQ (Enzo Life Sciences) was then added for $30 \mathrm{~min}$ for detection of cellular zinc before its washout (three washes) and analyses by confocal microscopy (Zeiss LSM880).

Quantification of cellular ATP levels. ARPE-19 and HCT116 p53 $3^{+/+}$cells were seeded in 96-well opaque plates at a density of 7500 cells/well. $24 \mathrm{~h}$ after seeding, cells were treated for $20 \mathrm{~h}$ with a range of concentrations of $\left[\mathrm{L}_{2} \mathrm{Cu}_{3}\right]^{6+},\left[\mathbf{L}_{2} \mathrm{Zn}_{3}\right]^{6+}$, $\left[\mathbf{L}_{2} \mathrm{Mn}_{3}\right]^{6+}$, or vehicle control (2-fold serial dilution from 100-3.125 $\mu \mathrm{M}$ ) before determining total cellular ATP content by quantification of luminescence (CellTiterGlo $^{\circledR}$ assay, Promega). ATP levels were normalised relative to levels in vehicle control-treated cells.

Cell treatment for preparation of whole cell protein lysates. ARPE-19 and HCT116 p53 $3^{+/+}$cells were seeded at a density of $3 \times 10^{5}$ (ARPE-19) or $5 \times 10^{5}$ (HCT116 p53 ${ }^{+/+}$) in T25 flasks. $24 \mathrm{~h}$ after seeding, cells were treated with $10 \mu \mathrm{M}$ of $\left[\mathbf{L}_{2} \mathrm{Cu}_{3}\right]^{6+},\left[\mathbf{L}_{2} \mathrm{Zn}_{3}\right]^{6+}$, or vehicle control for $4 \mathrm{~h}$ (Fig. $8 \mathrm{~b}$ ) or $5 \mu \mathrm{M}$ of $\left[\mathbf{L}_{2} \mathrm{Cu}_{3}\right]^{6+}$, $\left[\mathbf{L}_{2} \mathrm{Zn}_{3}\right]^{6+}$, or vehicle control for $40 \mathrm{~h}$ (Fig. 10). Cells were then harvested and lysed in RIPA buffer (Sigma) with the protein concentration of lysates determined by the BCA assay.
Immunoblotting. Protein lysates and recombinant proteins were resolved on 15\% SDS polyacrylamide gels. Proteins were electroblotted onto nitrocellulose membrane by wet transfer in 1xTris Glycine buffer (Biorad) at $35 \mathrm{~mA}$ overnight at room temperature ${ }^{62}$. After blocking of membranes, these were incubated with primary antibody overnight at $4{ }^{\circ} \mathrm{C}$ before addition of rabbit or mouse secondary antibody (HRP-conjugated; 1:5000, Dako P0448 or P0260) for $1 \mathrm{~h}$ at room temperature and development of blots by enhanced chemiluminescence. Primary antibodies were: anti-Src (total) (Cell Signalling Technology \#2123 1:1000), anti-phosphorylated Src (Y527) (Cell Signalling Technology \#21055 1:1000), anti-phosphorylated Src (Y416) (Cell Signalling Technology \#69435 1:1000), anti-AMPKa (total) (Cell Signalling Technology \#2532 1:1000), anti-phosphorylated AMPKa (T172) (Cell Signalling Technology \#2535 1:1000), anti-AMPK $\beta 1$ (total) (Cell Signalling Technology \#4150 1:1000), anti-phosphorylated AMPK $\beta 1$ (S108) (abcam ab156890 1:500), anti-phospho-Tyr (pan) (Cell Signalling Technology \#8954 1:2000), antip53 (Santa Cruz, DO-1 clone, 1:1000,), anti-phosphorylated LDH-A (Y10) (Cell Signalling Technology \#8176 1:1000), anti-LDH-A/B (total) (abcam ab134187 1:5000), anti- $\beta$-actin (Merck MAB1501, 1:40,000). Quantification of signals was performed by densitometry using Image J software. Uncropped and unprocessed scans are provided in the Source Data file.

Reporting summary. Further information on research design is available in the Nature Research Reporting Summary linked to this article.

\section{Data availability}

The X-ray crystallographic data reported in this study have been deposited at the Cambridge Crystallographic Data Centre (CCDC), under deposition number CCDC 2005221 - 005132, 2005133, 2005186, 2005189 and 2005190. This data can be obtained free of charge from The Cambridge Crystallographic Data Centre via www.ccdc.cam.ac. uk/data_request/cif. The data that supports the findings of this study are available in the Source Data file or from the corresponding authors upon reasonable request. Source data are provided with this paper.

Received: 9 June 2020; Accepted: 26 May 2021;

Published online: 23 June 2021

\section{References}

1. Matsumoto, Y. et al. A landmark in drug discovery based on complex natural product synthesis. Sci. Rep. 9, 8656 (2019).

2. Lehn, J. Supramolecular Chemistry. Science 260, 1762-23 (1993).

3. Lehn, J. M. Perspectives in supramolecular chemistry-from molecular recognition towards molecular information processing and self-organization. Angew. Chem. Int Ed. 29, 1304-1319 (1990).

4. Lehn, J.-M., Supramolecular Chemistry, (VCH, Weinheim, 1995).

5. Steed, J. W. \& Atwood, J. L. Supramolecular Chemistry, (John Wiley and Sons, Chichester, 2000)

6. Hannon, M. J. \& Childs, L. J. Helices and helicates: beautiful supramolecular motifs with emerging applications. Supramol. Chem. 16, 7-22 (2004).

7. Albrecht, M. "Let's twist again" double-stranded, triple-stranded, and circular helicates. Chem. Rev. 101, 3547-3498 (2001).

8. Albrecht, M. Dicatechol ligands: novel building-blocks for metallosupramolecular chemistry. Chem. Soc. Rev. 27, 281-288 (1998).

9. Piguet, C., Bernardinelli, G. \& Hopfgartner, G. Helicates as versatile supramolecular complexes. Chem. Rev. 97, 2005-2062 (1997).

10. Ahmedova, A. Biomedical applications of metallosupramolecular assemblies structural aspects of the anticancer activity. Front. Chem. 6, 620 (2018).

11. Sepehrpour, H., Wenxin, F., Sun, F. Y. \& Stang, P. J. Biomedically relevant self-assembled metallacycles and metallacages. J. Am. Chem. Soc. 141, 14005-14020 (2019)

12. Cook, T. R., Vajpayee, V., Lee, M. H., Stang, P. J. \& Chi, K.-W. Biomedical and biochemical applications of self-assembled metallacycles and metallacages. Acc. Chem. Res. 46, 2464-2474 (2013).

13. Kaner, R. A. \& Scott, P. Metallohelices: potential mimetics of $\alpha$-helical peptides in cancer treatment? Future Med. Chem. 7, 1-4 (2015).

14. Bruijnincx, P. C. A. \& Sadler, P. J. New trends for metal complexes with anticancer activity. Curr. Opin. Chem. Biol. 12, 197-206 (2008).

15. Hannon, M. J., Moreno, V., Prieto, M. J., Moldrheim, E., Sletten, E., Meistermann, I., Isaac, C. J., Sanders, K. J. \& Rodger, A. Intramolecular DNA coiling mediated by a metallo-supramolecular cylinder. Angew. Chem. Int. Ed. 40, 880-884 (2001).

16. Brabec, V. et al. Metallohelices with activity against cisplatin-resistant cancer cells; does the mechanism involve DNA binding? Chem. Sci. 4, 4407-4416 (2013).

17. Richards, A. D., Rodger, A., Hannon, M. J. \& Bolhuis, A. Antimicrobial activity of an iron triple helicate. Int. J. Antimicro. Agents 33, 469-472 (2009). 
18. Faulkner, A. D. et al. Asymmetric triplex metallohelices with high and selective activity against cancer cells. Nat. Chem. 6, 797-803 (2014).

19. Allison, S. J. et al. Ruthenium-containing linear helicates and mesocates with tuneable p53-selective cytotoxicity in colorectal cancer cells. Angew. Chem. Int. Ed. 57, 9799-9804 (2018).

20. Han, J. et al. Bioconjugation strategies to couple supramolecular exofunctionalized palladium cages to peptides for biomedical applications. Chem. Commun. 53, 1405-1408 (2017).

21. Lewis, J. E. M., Gavey, E. L., Cameron, S. A. \& Crowley, J. D. Stimuliresponsive $\mathrm{Pd}_{2} \mathrm{~L}_{4}$ metallosupramolecular cages: towards targeted cisplatin drug delivery. Chem. Sci. 3, 778-784 (2012).

22. Chen, L., Berry, S. N., Wu, X., Howe, E. N. W. \& Gale, P. A. Advances in anion receptor. Chem. Chem. 1, 61-141 (2020).

23. Yang, D., Zhao, J., Yanga, X.-J. \& Wu, B. Anion-coordination-directed selfassemblies. Org. Chem. Front. 5, 662 (2018).

24. Vilar, R. Anion-templated synthesis. Angew. Chem. Int. Ed. 42, 1460-1477 (2003).

25. Rice, C. R. Metal-assembled anion receptors. Coord. Chem. Rev. 250, 3190-3199 (2006).

26. Custelcean, R. Anion encapsulation and dynamics in self-assembled coordination cages. Chem. Soc. Rev. 43, 1813-1824 (2014).

27. Ballester, P. Anion binding in covalent and self-assembled molecular capsules. Chem. Soc. Rev. 39, 3810-3830 (2010).

28. Gale, P. A., Davis, J. \& Quesada, R. Anion transport and supramolecular medicinal chemistry. Chem. Soc. Rev. 46, 2497 (2017).

29. Zhang, S. et al. Squaramide-based synthetic chloride transporters activate TFEB but block autophagic flux. Cell Death Dis. 10, 242 (2019).

30. Wu, X., Howe, E. N. W. \& Gale, P. A. Supramolecular transmembrane anion transport: new assays and insights. Acc. Chem. Res. 51, 1870-1879 (2018).

31. Rice, C. R., Slater, C., Faulkner, R. A. \& Allan, R. A. Self-assembly of an anionbinding cryptand for the selective encapsulation, sequestration, and precipitation of phosphate from aqueous systems. Angew. Chem. Int. Ed. 40, 13255-13259 (2018)

32. Wurdak, H. et al. An RNAi screen identifies TRRAP as a regulator of brain tumor-initiating cell differentiation. Cell. Stem Cell. 6, 27-47 (2010).

33. Polson, E. S. et al. KHS101 disrupts energy metabolism in human glioblastoma cells and reduces tumor growth in mice. Sci. Transl. Med 10, eaar2718 (2018).

34. Dunn, K. C., Aotaki-Keen, A. E., Putkey, F. R. \& Hjelmeland, L. M. ARPE-19, a human retinal pigment epithelial cell line with differentiated properties. Exp. Eye Res. 62, 155-169 (1996)

35. Soule, H. D. et al. Isolation and characterization of a spontaneously immortalized human breast epithelial cell line, MCF-10. Cancer Res. 50, 6075-86 (1990).

36. Cao, R., Müller, P. \& Lippard, S. J. Tripodal tris-tacn and tris-dpa platforms for assembling phosphate-templated trimetallic centers. J. Am. Chem. Soc. 132, 17366-17369 (2010).

37. Hunter, T. Protein kinases and phosphatases: the yin and yang of protein phosphorylation and signaling. Cell 80, 225-236 (1995).

38. Cohen, P. Protein kinases - the major drug targets of the twenty-first century? Nat. Rev. Drug Disco. 1, 309-315 (2002).

39. Zhao, J. Cancer stem cells and chemoresistance: the smartest survive the raid. Pharm. Therapeut 160, 145-58 (2016)

40. Thomas, S. M. \& Brugge, J. S. Cellular functions regulated by Src family kinases. Annu Rev. Cell Dev. Biol. 13, 513-609 (1997).

41. Wu, P., Nielsen, T. E. \& Clausen, M. H. FDA-approved small-molecule kinase inhibitors. Trends Pharmacol. Sci. 36, 422-439 (2015).

42. Pawson, T. Specificity in signal transduction: from phosphotyrosine-SH2 domain interactions to complex cellular systems. Cell 116, 191-203 (2004).

43. Hardie, D. G., Ross, F. A. \& Hawley, S. A. AMPK: a nutrient and energy sensor that maintains energy homeostasis. Nat. Rev. Mol. Cell. Biol. 13, 251-262 (2012).

44. Warden, S. M. et al. Post-translational modifications of the beta-1 subunit of AMP-activated protein kinase affect enzyme activity and cellular localization. Biochem J. 354, 275-283 (2001).

45. Hunter, T. A tail of two src's: mutatis mutandis. Cell 49, 1-4 (1987).

46. Carpenter, M. C., Lo, M. N. \& Palmer, A. E. Techniques for measuring cellular zinc. Arch. Biochem. Biophysics 611, 20-29 (2016).

47. Blume-Jensen, P. \& Hunter, T. Oncogenic kinase signalling. Nature 411, 355-65 (2001).

48. Chan, L. L.-Y. et al. A novel image-based cytometry method for autophagy detection in living cells. Autophagy 8, 1371-82 (2012).

49. Lu, Z. \& Hunter, T. Metabolic kinases moonlighting as protein kinases. Trends Biochemical Sci. 43, 301-310 (2018).

50. Horn, H. F. \& Vousden, V. H. Coping with stress: multiple ways to activate p53. Oncogene 26, 1306-16 (2007).

51. Sheldrick, G. M. SHELXTL, Version 6.12 (Bruker Analytical X-ray Systems, Inc., Madison, WI, 2000)
52. Bourhis, L. J., Dolomanov, O. V., Gildea, R. J., Howard, J. A. K. \& Puschmann, $\mathrm{H}$. The anatomy of a comprehensive constrained, restrained refinement program for the modern computing environment - Olex2 dissected. Acta Cryst. A71, 59-75 (2015).

53. Sheldrick, G. M. SADABS: A Program for Absorption Correction (University of Göttingen, Germany, 1996).

54. Bunz, F. et al. Requirement for p53 and p21 to sustain G2 arrest after DNA damage. Science 282, 1497-1501 (1998).

55. Hastie, C. J., McLauchlan, H. J. \& Cohen, P. Assay of protein kinases using radiolabeled ATP: a protocol. Nat. Protoc. 1, 968-971 (2006).

56. Bain, J. et al. The selectivity of protein kinase inhibitors: a further update. Biochem J. 408, 297-315 (2007).

57. Durinck, S., Spellman, P., Birney, E. \& Huber, W. Mapping identifiers for the integration of genomic datasets with the R/Bioconductor package biomaRt. Nat. Protoc. 4, 1184-1191 (2009).

58. Durinck, S. et al. BioMart and Bioconductor: a powerful link between biological databases and microarray data analysis. Bioinformatics 21, 3439-3440 (2005)

59. R Core Team. $R$ : A language and environment for statistical computing. ( $\mathrm{R}$ Foundation for Statistical Computing, Vienna, Austria, 2019). https://www.Rproject.org/.

60. R Studio Team. Studio: Integrated Development for $R$ (RStudio, Inc., Boston, MA, 2015). http://www.rstudio.com/.

61. Eid, S., Turk, S., Volkamer, A., Rippmann, F. \& Fulle, S. KinMap: a web-based tool for interactive navigation through human kinome data. BMC Bioinforma. 18, 16 (2017).

62. Allison et al. Identification of LDH-A as a therapeutic target for cancer cell killing via (i) p53/NAD(H)-dependent and (ii) p53-independent pathways. Oncogenesis 3, e102 (2014).

\section{Acknowledgements}

The authors would like to thank University of Huddersfield for financial support.

\section{Author contributions}

C.R.R., S.J.A. and R.M.P. conceived and designed the experiments and worked on the manuscript. S.J.A., H.W. and H.B.S.G. performed the mechanistic experiments. C.J.C. synthesis of the complexes and crystal structures. R.A.F. performed NMR and UV-Vis studies. C.R.R. collection of crystallography data. R.M.P., S.J.A. and E.P. cytotoxic studies and other cellular studies. J.O.L. elucidation of the mechanism of action. J.B. analysis of the kinome map. J.H. and M.G. obtained the confocal images.

\section{Competing interests}

The authors declare no competing interests.

\section{Additional information}

Supplementary information The online version contains supplementary material available at https://doi.org/10.1038/s41467-021-23983-3.

Correspondence and requests for materials should be addressed to S.J.A., R.M.P. or C.R.R

Peer review information Nature Communications thanks Bruce Kemp and the other anonymous reviewer(s) for their contribution to the peer review of this work. Peer reviewer reports are available.

Reprints and permission information is available at http://www.nature.com/reprints

Publisher's note Springer Nature remains neutral with regard to jurisdictional claims in published maps and institutional affiliations.

Open Access This article is licensed under a Creative Commons Attribution 4.0 International License, which permits use, sharing, adaptation, distribution and reproduction in any medium or format, as long as you give appropriate credit to the original author(s) and the source, provide a link to the Creative Commons license, and indicate if changes were made. The images or other third party material in this article are included in the article's Creative Commons license, unless indicated otherwise in a credit line to the material. If material is not included in the article's Creative Commons license and your intended use is not permitted by statutory regulation or exceeds the permitted use, you will need to obtain permission directly from the copyright holder. To view a copy of this license, visit http://creativecommons.org/ licenses/by/4.0/.

(c) The Author(s) 2021 